\title{
Review article: Journalism innovation research, a diverse and flourishing field (2000-2020)
}

\author{
José-Alberto García-Avilés
}

Nota: Este artículo se puede leer en español en:

http://www.profesionaldelainformacion.com/contenidos/2021/ene/garcia_es.pdf

How to cite this article:

García-Avilés, José-Alberto (2021). "Review article: Journalism innovation research, a diverse and flourishing field (2000-2020)". Profesional de la información, v. 30, n. 1, e300110.

https://doi.org/10.3145/epi.2021.ene.10

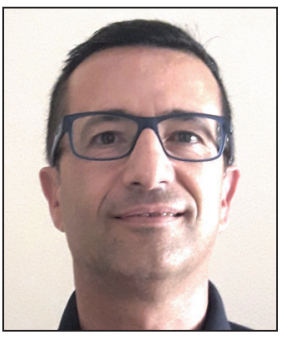

\section{José-Alberto García-Avilés}

https://orcid.org/0000-0001-7854-3476

Universidad Miguel Hernández de Elche

Departamento de Ciencias Sociales y Humanas

Av. de la Universidad, $\mathrm{s} / \mathrm{n}$.

30202 Elche (Alicante), Spain

jose.garciaa@umh.es

\begin{abstract}
The aim of this article is to review research in media innovation through a holistic, analytical, and concise approach. Although research in journalism innovation has experienced considerable growth in recent years, theoretical, methodological, and systematic contributions have received little and fragmented attention. Three hundred and two peer-reviewed publications, in both English and Spanish, were included in the sample. The most researched areas included diffusion theory, management, organizational culture, professional profiles, business models, genres and content, tools and technology, media labs and start-ups. Other less developed areas, such as policy, methodology, ethics, or journalism education, are also discussed. Finally, a number of proposals regarding further research on journalism innovation, considering the effect of Covid-19 on the media, are discussed.
\end{abstract}

\section{Keywords}

Journalism innovation; Media innovation; Diffusion of innovation; Digital journalism; Innovation research; Distribution; Management; Organizational culture; Professional profiles; Processes; Technologies; Policies; Business models; Methodologies; Ethics; Societal impact; Review article.

\section{Funding}

This article forms part of the findings of the research project "Journalism innovation in democratic societies: Index, impact and prerequisites in international comparison (Joln-DemoS)", funded by the Deutsche Forschungsgemeinschaft (DFG, German Research Foundation), Project-ID 438677067.

https://gepris.dfg.de/gepris/projekt/438677067

\section{Introduction}

The aim of this article is to review academic research in media innovation. A review article is by nature a limited and incomplete task since it is impossible to do justice to the enormous volume of academic publications in this field. The approach I adopted is necessarily holistic, analytical and concise, and aims to shed light on the evolution of research (diachronic perspective), explore the main areas of research (dialogical perspective), and propose future lines of enquiry (prospective perspective). Although research into journalism innovation has undergone considerable growth in recent years, theoretical, methodological, and systematic contributions have received little and fragmented attention, as reflected in several literature reviews (Bleyen et al., 2014; Dogruel, 2015). 
I explore in detail the growth of scientific research in journalism innovation, identifying key areas where significant progress has been made, as well as others that remain understudied. The most researched areas include diffusion theory, management, organizational culture, professional profiles, business models, genres and content, tools and technology, media labs, and entrepreneurial journalism. Other areas, such as policy, methodology, history, ethics, or journalism education -underrepresented in the literature- are also discussed. Finally, I make some conclusions and reflections on future research in media innovation, taking into account the effect of the Covid-19 pandemic on journalism.

Scientific works published in both English and Spanish were included as there is a considerable body of research in media innovation in Spain and Latin American countries such as Argentina, Brazil, Chile, Colombia, Mexico, Peru, and Portugal, to mention just a few. In this way, I hope to showcase publications in journals from the Spanish, non-English-speaking academic world, such as Ámbitos, Brazilian Journalism research, Communication and society, Cuadernos.info, Profesional de la información, Estudios sobre el mensaje periodístico, Miguel hernández communication journal, Observatorio (OBS*), Revista mediterránea de comunicación, Revista de comunicación, Revista latina de comunicación social, Textual \& visual media, and ZER. The most cited journals in media innovation in the English-speaking world are Convergence: the international journal of research into new media technologies, Digital journalism, International journal on media management, Journal of communication, Journal of media business studies, Journalism, Journalism \& mass communication quarterly, Journalism practice, Journalism studies, New media \& society, Nordicom review, and The journal of media innovations. Books and chapters produced by publishers such as Amsterdam University Press, Edward Elgar Publishing, MIT Press, Nordicom, Palgrave Macmillan, Peter Lang, Routledge, Sage, Springer, and Wiley were also included in the sample.

The need to establish a clear definition of journalism innovation and its implications, to understand its particularities, and to explore different research traditions is not an exclusively academic requirement. In this respect, it is not surprising that many innovations are implemented in the hope of finding solutions to the problems currently facing journalism. Thus, innovation theory helps to illustrate current developments in the media sector and provides a useful framework for analyzing news organizations' transformation and the future of journalism in an uncertain post-Covid-19 scenario.

\section{Methodology}

The author is indebted to the many academics who have explored the fertile grounds of this discipline, outlined the main areas of study, and engaged in fruitful discussions. Mitchelstein and Boczkowski (2009) reviewed international research in digital journalism, paying special attention to innovation; Bleyen et al. (2014) provided an excellent classification of media innovations; Dogruel (2015) carried out a systematic analysis of innovation research in media management and economics; Foss and Saebi (2017) focused on business model innovation research; Belair-Gagnon and Steinke (2020) underlined the growing interest of journalism academics in innovation; while Klaß (2020) reviewed the literature on open innovation in this field of research. Their work cleared the way and provided a valuable starting point for this reviewer.

In this review, the methodological process followed these basic steps:

1) Identification of the object of study and the period to be analyzed, namely journalism and media innovation from 2000 to 2020.

2) Selection of sources: peer-reviewed publications in journals and books, both in English and Spanish. Publications that were not subject to peer review were excluded, as were conference papers, proceedings, and professional articles and reports.

3) Search in Web of Science, ProQuest, EBSCO, and Google Scholar to obtain a preliminary list of publication titles, abstracts and final descriptors, using the key words innovation, journalism innovation, media innovation, newsroom innovation, news innovation, and diffusion of innovation.

4) Management and filtering of the search results. All the article abstracts were read to identify their main topic(s) and contributions, eliminating those that did not match the original object of study. Thus, articles that exclusively referred to innovation in the service or culture industries (film, books, music, entertainment television, videogames, etc.) were excluded from the analysis. Studies that focused on innovation in platforms (e.g., Google or social media sites) and did not refer to journalism were also eliminated. This selection process resulted in a final sample of 302 publications.

5) Analysis of the publications. Taking into account the approaches for conducting a literature review, the analysis presented here follows that of West and Bogers (2014) and includes three methodological steps. The first consists of a systematic search, the second is based on categories defined through content analysis, while in the third, the selected articles are qualitatively analyzed, reviewing the abstracts, and, if necessary, the full text, using key structural categories and including basic descriptive information.

6) The design, structure, and writing of the article, following the contributions and conceptual frameworks established through the analysis of the publications. 


\section{Concept of journalism innovation}

The concept of journalism innovation is vaguely defined in the academic literature. Few investigations offer a precise definition of it or provide a solid conceptual approach (Bleyen et al., 2014, p. 29). While innovation is closely related to change, since news organizations innovate to influence their environment or to face disruptions, it should not be equated to change itself, because it is based on complex dynamic social processes that go beyond the control of single actors in diverse media contexts. A shared understanding of the concept should be the starting point for any relevant contribution to this field of research.

Although a connection between media innovations and social change is quite relevant (Bruns, 2014; Krumsvik et al., 2019), theoretical frameworks on how to approach and evaluate the impact of journalism innovations on the quality of news and, in a broader sense, their influence on democratic societies remain underdeveloped. The variety of subjects, concepts and perspectives on media innovation is considerable, so we must consider the different dimensions (e.g., organizational, managerial, institutional, ethical, societal, technological) that make up its very nature and underline its interdependency (Küng, 2013, p. 9).

This range of perspectives is echoed in the scientific literature. Research on news innovation has been conducted based on the News Ecology Model (Lowrey, 2012; Lowrey; Sherrill; Broussard, 2019), the Actor-Network Theory (Domingo, 2008; Plesner, 2009; Schmitz-Weiss; Domingo, 2010; Spyridou et al., 2013), Action Research (Grubenmann, 2016; Wagemans; Witschge, 2019), Marxist theory criticizing innovations in information and communications technologies (Sekloča, 2015), and the Open Innovation framework (Aitamurto; Lewis, 2013; Klaß, 2020; Lewis; Usher, 2013).

Dogruel (2013, pp. 36-40) highlights four basic characteristics of media innovation: its newness, its economic and social exploitation, its communicative implications, and its character as a process. This assessment of media innovations expands their role as indicators of change rather than only being catalysts for transformation processes in businesses (p. 41). Steensen (2009), drawing on Boczkowski (2004), argues that a theory of innovation in online news comprises five factors: newsroom autonomy, work culture, the role of management, the relevance of technology, and the input of innovative individuals.

Let us consider three basic definitions of media innovation provided by academics.

Pavlik (2013, p. 183) defines news innovation as

"the process of taking new approaches to media practices and forms while maintaining a commitment to quality and high ethical standards."

According to Pavlik (2013), innovation is driven largely by technological advances and economic challenges along four dimensions (p. 183): (a) creating, delivering and presenting quality news content, (b) engaging the public in an interactive news discourse; (c) employing new methods of reporting optimized for the digital age, and (d) developing management and organizational strategies for a mobile networked environment.

Schmitz-Weiss and Domingo (2010, p. 1158) define innovation in online newsrooms as

"the development by the online staff of new production practices, new product features or new technological tools, which can include systems, programs or applications that help in the distribution, acquisition, processing, display and storage of news and content that online journalists work with."

García-Avilés et al. (2018, p. 27) define journalism innovation as

"the capacity to react to changes in products, processes and services through the use of creative skills that allow a problem or need to be identified, and to solve it through a solution that results in the introduction of something new that adds value to customers and to the media organization."

These two last definitions have much in common. Both include interrelated elements ("production practices, product features, technological tools", "products, processes, services") and link innovation to certain results in existing processes ("distribution, acquisition, processing, display and storage of news", "the introduction of something new that adds value to customers and to the media organization"), emphasizing how a company captures a share of the value generated through innovation. Therefore, we could argue that an essential aspect of media innovation lies in its transformative value, which modifies and improves the organization's performance.

The study of journalism innovations should go beyond media practices and technologies to include essential areas such as societal change. Barnhurst (2013) criticizes the concept of innovation itself for being overly concerned with technology, stressing the role of the public as a vital concept for developing public service journalism (pp. 218-219). Barnhurst (2013) recommends that journalists distance themselves from product innovation and focus on serving the public. His arguments underline the importance of social innovation discussed by other scholars (Bruns, 2014; Khajeheian; Tadayoni, 2016; Storsul; Krumsvik, 2013). As Bruns (2014, p. 24) states,

Theoretical frameworks on how to approach and evaluate the impact of journalism innovations on democratic societies remain underdeveloped 
"media practices, social practices, and society itself are inherently and inextricably entwined in contemporary mediatized society, however - a change to any one of these components will therefore necessarily also cause changes to the others. Innovation in media practices is, then, inevitably also a source of social and societal change."

In journalism, no innovation is possible without the essential component of ethics, because the very activity of reporting itself is based on a commitment to truth and ethical standards (García-Avilés, 2016). Journalists initially tend to frame innovations as threats to ethical principles, as something that must be resisted on moral grounds; however, such resistance can easily become an impediment to thinking productively about innovation (Singer, 2014). As Singer (2014, p. 78) writes,

"the ethical compromises that journalists fear - not entirely without justification - stem primarily from pressures that originate in a shortage of money, not an excess of innovation."

However, to date little attention has been given to the ethics of journalism innovation.

The lack of positive results in the media market has led to a reasonable criticism of academia's emphasis on innovation. Some authors argue that a focus on innovation obscures the structural, historical, and cultural conditions that exert pressure on journalism (Creech; Nadler, 2018) and thus,

"innovation becomes a mode of civic being that assumes the conditions of the market should guide public life" (p. 13).

An idealized notion of media innovation, often coupled with technologically deterministic discourses, leads to the rejection of normative notions of journalism in order to align with market-oriented and industry-wide business trends. This conceptual vagueness leads to a somewhat chaotic vision of journalism's future (Creech; Mendelson, 2015).

We argue that, in addition to more research, a deeper, evidence-based theoretical framework is needed regarding

"the actors, dynamics and factors involved in the processes and theories that acknowledge the changing nature of journalism" (Schmitz-Weiss; Domingo, 2010, p. 1158).

Social processes may interact with the quality certification mechanisms of innovative features in media products, in what Schweizer (2003) calls "stylistic innovations", since

"aesthetic enjoyment as a key part of consumer satisfaction arises from the recognition of stylistic differences" (p. 21).

To analyze these complex interdependencies the field of journalism innovation requires a combination of normative theories regarding the media (Christians et al., 2009) and

"theoretical and empirical approaches from economic and social innovation theory as well as media-specific frameworks" (Dogruel, 2014, p. 62).

The thesis that media innovations are only viable in the long term if they contribute to the quality of news (Pavlik, 2013) has not been sufficiently empirically tested yet. In this regard, journalism innovation should no longer focus only on product- and technology-related aspects, but also on news quality and social impact. Besides their economic value, media innovations have an influence on society, organizations, and citizens.

\author{
The study of journalism innovations \\ should go beyond media practices and \\ technologies to include essential areas \\ such as societal change
}

\section{Typologies of media innovation}

Journalism innovation explores changes in several aspects of the media landscape - from the development of new platforms to novelties in content production, distribution, and commercialization. Francis and Bessant (2005) identify four ways of targeting innovation: Product, Process, Position and Paradigmatic Innovation, and define them as wide categories with blurred boundaries. Storsul and Krumsvik (2013) list ten key factors which influence media innovation: (1) technology, (2) market opportunities and user behavior, (3) behavior of competitors, (4) regulation, (5) industry norms, (6) company strategy, (7) leadership and vision, (8) organizational structure, (9) capacity and resources, and (10) culture and creativity.

In traditional Schumpeterian literature, there is general agreement that innovations can be either "radical" or "incremental" according to the degree of change they bring about in product or service value creation (Storsul; Krumsvik, 2013). Both authors provide an overview of the conceptualization of innovation from economic, management and constructivist approaches. Product innovation encompasses both technologies and services offered by media organizations; process innovation incorporates changes in the ways that products or services are created and delivered, such as new systems of producing, packaging or distributing products, as well as organizational changes in the company; position innovation refers to changes in the framing of products and services, such as in brand identity, strategic positioning or addressing new target audiences; and paradigmatic innovation examines changes in an organization's basic orientation or mindset, such as the restructuring of its strategies of value creation and business models. 
Lindmark et al. (2013, p. 133) propose a typology of media innovation along two key dimensions:

1. Type of innovation: (1) a content innovation that can either be in the core (a theme or message) or in the form (a new stylistic feature); (2) a consumption/medium innovation (a new way of consuming content); (3) a production and distribution innovation (a new means of creating, producing, reproducing, distributing or showing content); and (4) a business model innovation (a new business model, including the reorganization of an industrial sector).

2. Temporal aspect (maturity of innovation, closeness to market): long-term, medium-term, and short-term.

Belair-Gagnon and Steinke (2020, p. 7) define six mechanisms that generate innovation: participative (open, distributed, networked, and collaborative); normative (friction, resistance, and normalization); disruptive (quick, fragmented change); diversity (gender, race, disabilities, etc.); emotive (humor, fun, and play); and experimental (disruptive). Both authors (p. 14) argue that studies

"cast innovation as a means for organizations to improve work methods, foster compelling interactions with audiences, organize and align talents and assets, create complementary products and services, and connect with others to create value."

Hess and Waller (2020a) advocate for a six-dimensional approach to shaping innovation for regional news organizations that highlights the connections between digital, social, cultural, political, economic, and environmental concerns.

These approaches show that although most of the literature does not relate to a unifying framework of journalism innovation, a growing body of studies do consider a wide set of elements and provide a valuable framework to define the main fields and objects of research.

\section{Research methods: an underdeveloped field}

Media innovation seems to be ill-defined and poorly captured by purely quantitative statistical methods (Bleyen et al., 2014), while the most common methodologies are not themselves very innovative. Research in this field is fragmented because of the existence of different contexts, definitions, and potential success factors (Habann, 2008). Issues such as the policy and regulatory context of the media sector, market composition, or technological development are rarely examined in empirical studies. Specific media innovations or case studies are often analyzed in one country, usually based on interviews of small samples of individuals. However, macro-level factors and their influence are barely studied, making it difficult to make systematic generalizations or rigorously develop theories. However, quantifying both research and development expenditure (innovation input) and the actual innovation volumes (innovation output) in terms of individual factors and overall performance cannot simply be based on parameters such as the number of patents registered in a sector during a particular period (Bleyen et al., 2014). Therefore, methodology design deserves special attention to enable solid, comparable research that builds upon common scientific knowledge on media innovation.

Habann (2008) examines the foundations of research methods in product innovation. He links product innovation to economic profitability and several intangible assets such as brand image, company skills, and customer knowledge, which may contribute to the success of an innovation. Thus,

"it might be appropriate to measure success by the extent to which defined goals have been met by the innovation project, as perceived by responsible managers" (2008, p. 69).

Carvajal et al. (2015) develop a methodological tool to investigate models of journalism production, distribution, organization and commercialization, and systematically analyze how they influence a market. They outline a system of analysis based on sample selection, the definition of innovations in key areas, and quantitative and qualitative analysis. This methodology was applied in a study of the Spanish media that concluded that most innovations occurred in the areas of product, distribution, and interaction with the audience (De-Lara et al., 2015; García-Avilés et al., 2018). While most innovative initiatives were incremental with gradual improvements of existing products or services, a few radical innovations were implemented, mainly by digital-only news outlets.

According to Steensen (2013), the prevailing discourse of innovation and change should be complemented by competing perspectives of transformation and practice to better understand how and why new media and innovative practices develop. Trappel (2015, p. 29) proposes carrying out interdisciplinary research on communication innovation to evaluate improvements or deterioration in democratic values such as freedom, equality, diversity, solidarity and participation, with a view to balancing industry research, which focuses on the commercial success of innovations.

Studies on media innovations cover three basic levels (Dogruel, 2013, p. 40):

a) The macro-level, which explores institutional policies, market factors and the socioeconomical context (Túñez-López et al., 2019, Valero-Pastor, 2019; Vázquez-Herrero et al., 2020) to examine the impact of innovation policies in specific areas, such as the Flemish broadcasting sector (Lindmark et al., 2013). Innovation policies can help the media industry meet development needs. In most European countries, innovation subsidies are designed to finance only time-limited projects with specific deliverables aimed at improving the situation of news organizations (Van-Kranenburg, 2017). Although the need to reform media policies is widely acknowledged by policy makers, there is no consensus as to what measures should be implemented (Van-Kranenburg, 2017). 
b) The medium-level, which focuses on companies as agents of innovation in a market or country. Studies include the analysis of management, organizational aspects and structures, and the implementation and diffusion of innovations in news organizations (Baumann, 2013; Colussi; Gomes-Franco; Melani, 2018; McKelvie; Wiklund, 2008; Nel; Milburn-Curtis; Lehtisaari, 2020).

c) The micro-level, which deals with individual agents of innovation (workers) and specific units, such as newsrooms, labs and start-ups, that have been identified as drivers of media innovation (Carlson; Usher, 2016; Westlund; Lewis, 2014).

It is very rare to find studies that holistically combine all three levels of analysis.

\section{The historical development of journalistic innovations}

Research on the history of journalism innovation tends to focus on legacy news organizations and on the disruptive role of technology, highlighting how newsrooms responded to, and resisted, change (Prenger; Deuze, 2017). The pioneers of innovation, understood as a group of journalists that incorporated new organizational forms and experimental practices ahead of mainstream changes, also played a role in the redefinition of journalism and its structural foundations (Hepp; Loosen, 2019). Legacy media, with traditional routines, products, and business models, have taken longer to realize that digital transformation was needed to face the disruption and that innovation was an opportunity for sustainability (Ashuri, 2013; García-Avilés; Martínez-Costa; Sádaba-Chalezquer, 2016; García-Avilés; Meier; Kaltenbrunner, 2017; Santos-Silva, 2020). Accordingly, a number of longitudinal studies have explored particular subjects in the development of legacy media innovations, such as the adoption of paywalls by online news outlets since the 1990s as a case of "retro-innovation" (Arrese, 2016), the ongoing processes of technological innovation in legacy media through the development of blogs and other 'Web 2.0' tools (Nielsen, 2012; Ostertag; Tuchman, 2012) or journalists' use of Twitter and the impact of news organizations' social media policies (Chadha; Wells, 2016; English, 2016; Oelrichs, 2020).

The rise of digital-only news outlets in the 2010s was a sign of the maturity of the online media market and contributed to the digital transformation of the industry (García-Avilés; Arias-Robles, 2016a). Some of these news outlets succeeded because they were able to connect with users' interests, promoted a more flexible workflow, and decentralized production and distribution systems (Sádaba-Chalezquer; García-Avilés; Martínez-Costa, 2016). Many digital-only players focused on experimentation and innovation from an early stage and adapted to the disruptive environment quicker than legacy media, as they could take fewer risks and their learning process was faster (Kaltenbrunner; Karmasin; Kraus, 2017).

A number of innovation studies focused on how technological tools and digital technologies changed news production and the consequences for journalistic work, examining their impact on news practices, hierarchies, and relationships in sometimes disruptive ways. As Steensen argues, online journalism research is

"dominated by a discourse on technological innovation" (2011, p. 11).

Academics have examined audience fragmentation and structural limits on media innovation (Picard, 2000), technology-driven innovation and its practical implications (Spyridou et al., 2013) and whether entrepreneurial journalism and news start-ups are successful (Sommer, 2018; Usher, 2017). In his classic study on newsrooms' adoption of online technologies, Boczkowski (2004) demonstrates how non-technological organizational and professional factors complicate journalism's conflicting relationship with technology. However, journalists have reacted to technological innovation in complex ways, from fear of disruption to reinvention (Meier; Bracker; Verhovnik, 2017; Powers, 2012).

Innovation is often defined in terms of technology and business and omits the socio-cultural component. Interactions between content and technology in the media industries might help explain differences in the receptiveness of businesses towards new technological opportunities (Kannengießer, 2020) in the case of public service media (Fernández-Quijada et al., 2015; Lowe; Stavitsky, 2016) or in specific national markets, such as Colombia (García-Perdomo; Magaña, 2020). Some studies adopt a technology-oriented perspective that regards technological innovation as the driving force of the changes in journalism (Moreira, 2017). In certain news organizations, innovation is used to mask economic and structural problems, rather than being framed as a solution to these problems (Evans, 2016). Digital innovation is usually driven by staff with experience and motivation (Schmitz-Weiss; Wulfemeyer, 2014).

Technology and content interact strongly with each other and should be linked to elements such as management, product, newsroom culture, and social engagement (Evans, 2016; García-Avilés, 2017). In their review of studies about online news production, Mitchelstein and Boczkowski (2009, p. 566) describe "a process of innovation as the interplay between technology and local contingencies", including people and organizational contexts that shape changes in online journalism. Innovation drives visions of journalism's future (Valanto; Kosonen; Ellonen, 2012), often displaying a fixation with anticipating technological change and emerging business models while tending to overlook journalism's sustained democratic value (Creech; Nadler, 2018, p. 194).

Considering the vast amount of literature on technological innovations in journalism, one could be under the impression that the only possible form of innovation lies in the adoption of such technologies. In this regard, most academics neglect to explore why news organizations incorporate digital media in their work and products. Rather, they focus on how the incorporation takes place (the process) and the results of doing so. 


\section{Diffusion of innovations}

According to the seminal work of Rogers (2003, p. 5), diffusion is

"the process by which an innovation is communicated through certain channels over time among the members of a social system."

Diffusion of Innovations (DOI) theory in media research is conceptualized as a process that includes structural and practical factors derived from professionals' inputs in different areas of production (Lund, 2008; Micó; Masip; Domingo, 2013). Rogers (2003) proposed an 'Innovation-Decision Process Model' to study the stages of adoption, which is essentially an information-seeking and information-processing activity in which individuals attempt to reduce uncertainty about the advantages and disadvantages of a specific innovation. Innovations emerge not only as a response to threats of instability in the media market, increasing industry competition and technological disruption; interactive audiences and social media also play a decisive role in helping reduce uncertainty and fostering early adoption (Atkin; Hunt; Lin, 2015; Garrison, 2001; Lievrouw, 2006).

The continuum of innovativeness (Rogers, 2003) is divided into five adopter categories: innovators, who introduce the innovations; early adopters, who are the first to implement them; early majority, the large number of individuals who adopt the innovations fairly quickly; late majority, who adopt them later, and laggards, who lag behind the rest. These categories are ideal prototypes based on observations of reality and are designed to make comparisons possible. Zhou (2008) proposes four adoption categories (voluntary adopters, forced adopters, resistant non-adopters, and dormant non-adopters), according to the voluntary nature of organizational members' innovation decision-making. As García-Avilés (2020b) argues, DOI researchers should be careful in analyzing the impact of internal communication, the role of institutional policies, the effects of the managerial strategies, and the importance of the installed learning inertia (Zhou, 2008).

Many elements, including the availability of information technology, adopters' past experiences, management support, availability of change agents, and communication process (Chua; Duffy, 2019; Ekdale et al., 2015;

\section{An innovative learning culture encoura- ges fresh and creative ideas to experi- ment with in newsrooms}

Singer, 2004; Wood-Adams, 2008) explain the adoption

of innovation decisions in news organizations. According to Zabel and Telkmann (2020), certain organizational drivers are especially important for the successful adoption of technological innovations, such as top management support, existence of an innovation champion, alignment with the company's innovation strategy, cooperation with internal IT and long-term planning for the accumulation of sustainable expertise within the companies. Lund (2008) emphasizes the significance of communication in DOI processes. Meier's (2007) study of how convergence as practice was diffused in the news agency Austria Presse Agentur also highlights the importance of managerial communication in eliminating organizational barriers.

Porcu (2017) studied innovative learning cultures within legacy media newsrooms and argued that the scarcity of academic attention to learning and innovation processes of journalists was

"the biggest gap in the media innovation literature" (p. 12).

Research shows that there are simmering tensions between journalism's organizational culture and the professional subcultures inherent in innovation. Paulussen et al. (2011, pp. 8-13) view the implementation of innovations as being heavily personality-driven and dependent on the willingness and agency of staffers. In this context, the DOI model in news organizations proposed by García-Avilés et al. (2019) considers specific factors which might help advance or hinder innovative practices within media companies and explores how innovations are embraced by early adopters (García-Avilés; Carvajal; Arias, 2018).

A growing body of literature relates to how journalism education programs address innovation and entrepreneurial initiatives in relation to changing industry circumstances, long-standing conceptualizations of occupational norms and curricular improvements (Drok, 2013; Manfredi-Sánchez, 2015; Manfredi-Sánchez; Ufarte-Ruiz; Herranz-de-la-Casa, 2019; Pavlik, 2013; Singer; Broersma, 2020). Reference is made to innovation in communication studies (Chasi; Rodny-Gumede, 2020), teaching data journalism (Hewett, 2016) and fostering creativity in digital journalism programs (Witschge; Deuze; Willemsen, 2019). However, although journalism students agree with the idea of innovation and see its value, they define change predominantly in terms of technology rather than more substantive cultural transformation (Broersma; Singer, 2020), while professionals demand more focus on journalism skills and standards (Ferrucci, 2018). In the Latin American context, a significant gap exists between academics and the profession regarding the definition of innovation and what it means to be innovative (Schmitz-Weiss et al., 2020).

Dogruel $(2014 ; 2015)$ regards literature on media innovation to be limited, with its narrow focus on diffusion, adoption and acceptance of the final technological pro-

Dogruel argues that innovation encompasses an entire cycle, from its invention to its diffusion or implementation, and calls for an integrated approach that aligns with all the stages of the innovation cycle 
duct that enters a market or is implemented by a news organization because it largely ignores the design and development stages of innovation. She argues that innovation encompasses an entire cycle, from its invention to its diffusion or implementation, and calls for an integrated approach that aligns with all the stages of the innovation cycle.

\section{Media innovation management}

The study of innovation management is crucial because it helps explain how the diffusion of innovations shapes the communication sector and provides a sustainable future (Dal-Zotto; Van-Kranenburg, 2008). However, a meta-analysis on innovation and media management studies found that most scholars did not directly address media management and focused on the use of technology (Sylvie; Schmitz-Weiss, 2012, p. 199). The emphasis of research on technological innovation reflects the fact that the media is one of a number of industries facing the emergence of potentially disruptive technologies.

Researchers have explored innovation through the lens of media management theory (Mierzejewska, 2011), which includes variety of perspectives:

a) Product innovation, which regards products, technologies, and innovations as a strategic element in the company's financial performance (Gershon, 2016);

b) Consumer behavior, examining the ways users consume the media and how they benefit from their consumption (Schoder et al., 2006);

c) The effects of adopting innovations on organizations and employees (Gholampour-Rad, 2017; Wood-Adams, 2008). In this regard, Järventie-Thesleff, Moisander and Villi (2014) found that management practices in print media outlets tend to be geared toward supporting incremental innovations, whereas practices in online platforms are oriented toward pursuing more radical innovations;

d) Leadership theory, in order to make strategic decisions at a time when sectors such as technology and telecommunications companies are driving innovation (Küng, 2013). The upper echelons of news organizations therefore need to update their knowledge (Appelgren; Nygren, 2019), including internal communication and coordination among organizational units with structures and processes that facilitate strategy, creativity, and innovation (Gade et al., 2018; García-Avilés, 2012; Küng, 2011).

Management strategies to drive institutional change, specifically regarding the professional journalist and 'news nerds', tend to give importance to data, analytics, and platform-related positions in order to boost competitiveness (Kosterich, 2019). Professionals are motivated to develop new skills and competencies as well as opportunities to redesign journalistic products and practices (Malmelin; Virta, 2016). Leenders, Farrell and Van-der-Wurff (2016) found that what is important for the capacity to innovate is the degree to which media professionals identify with the orientations of the company they work for. Along this line, Dogruel (2015) discusses theoretical and empirical concepts of innovations from a media management and media economics perspective and finds

"an emphasis on product and process innovations and a focus on micro- and meso-level approaches" (p. 153).

When changing the newsroom mindset and fostering innovation, management must engage in value-chain thinking and make story development a process less hierarchically driven and more networked (Sylvie, 2017, p. 102). Krumsvik (2015) explained the importance of digital skills necessary in process innovation and highlighted the conflict between the product innovation of online news features and the process innovation of multi-platform news production. Television managers from a broad cross section of small, medium, and large markets in the United States identified three primary areas in which they say they are innovating, including live reporting, social media, and on-demand television services (Imre; Wenger, 2020). According to both authors, the motivating factors for media innovation were audience preferences, economic drivers, and corporate influence. In addition, new technologies drove the diffusion process in local television news reports (Adornato, 2014).

Media organizations must be capable of managing the practices and processes in order to convert creative ideas into innovations in ambidextrous organizational settings. The role of management in providing supportive conditions for implementing innovations and balancing ambidextrous tensions is essential (Virta; Malmelin, 2017). A management style based on 'media Googlization' implies a strong shift for media companies, implementing processes that aim to take advantage of digital data, traffic, and advertising (Badillo; Bourgeois, 2020, pp. 190-191). However, according to both authors, these processes are accompanied by limited innovation because the priority has not been to fuel creativity in the production of quality news products.

The barriers and obstacles to innovation in journalism are closely related: insufficient capacity to innovate in basic training, a professional culture somewhat skeptical about innovation, and an educational landscape that does little to promote innovation lead to difficult conditions for the financing of journalistic innovations (García-Avilés et al., 2019). At the same time, the profession is increasingly associated with precarious working conditions, which can make it less attractive in terms of attracting the most talented managers (Küng, 2011) and might have a negative impact on the innovative capacity of key players in the industry.

The role of managers is essential in creating the conditions that drive innovation and mitigate tensions 


\section{Organizational culture and new professional profiles}

The impact of organizational culture on innovation processes across media outlets has been widely acknowledged (Gade; Perry, 2003). Regardless of company size, there tends to be an interrelation between organizational culture and innovative performance (Van-der-Wurff; Leenders, 2008). However, newsroom culture is a complex and intangible issue that defies standard measurement criteria. Journalists rely on a deeply embedded professional culture when adopting the innovations and projects implemented in their newsrooms (Kramp; Loosen, 2017; Ryfe, 2009a; 2009b). Intra-organizational collaboration between journalists, managers and technologists when launching innovations is difficult to accomplish in legacy media with traditional organizational cultures (Westlund; Krumsvik, 2014), while a long-established fear-driven defensive culture among journalists often becomes a barrier to the development of innovation in online news (Nguyen, 2008).

One of the core disruptive effects of media innovations is the evolution of professional identities, which results in more complex role relationships that are complemented by a reconfigured set of values and practices. Changes in journalistic practice sometimes involve the gradual transposition of previous schemas to renewed resources and procedures (Raetzsch, 2015), or the incorporation of journalistic standards that become more relevant, such as transparency (Koliska; Chadha, 2018). Both individual actors and structural elements can help overcome inertia and reinforce newsroom innovation (Paulussen, 2016; Steensen, 2009). Journalists tend to evaluate innovations based on their perceived potential to improve the quality of journalistic work, thus fostering a culture of collaboration (Paulussen; Geens; Vandenbrande, 2011). Indeed, coordination and collaboration between the various departments, in particular the Information Technology department, is increasingly linked to the development of innovation in the media (Westlund; Krumsvik; Lewis, 2021). However, conflicts emerge between news intrapreneurs, who adopt a logic of experimentation, audience orientation, and efficiency-seeking, and managers' logic of prioritizing news workflows, formats, and professional autonomy (Belair-Gagnon; Lewis; Agur, 2020).

Studies show that although a multi-platform strategy is effective in overcoming procedural inertia and maximizing the innovative capacities of newsrooms (Lischka, 2015), innovating in digital-first newsrooms is complicated and fuels internal tensions (Hendrickx; Picone, 2020). News processes and routines have been fundamentally altered to meet demands for multimedia, interactivity, and immediacy (Groves; Brown, 2020). Innovative outlets tend to increase collaboration among professionals, facilitate access to qualified knowledge sources, make workflows more flexible and allow interdepartmental cooperation (Valero-Pastor; Carvajal-Prieto, 2019; Valero-Pastor; Carvajal-Prieto; García-Avilés, 2019). Lewis and Usher (2013) consider how the characteristics of open-source culture are seeping into newsroom practice as journalists and technologists increasingly work together in developing innovative projects.

A newsroom's social climate that stimulates 'outside the box' thinking has been conceptualized by Porcu (2017) as an innovative learning culture, which is defined as a learning culture in the organization that triggers and fosters novel and creative ideas to experiment with and to learn from. Through an innovative learning culture framework, Porcu, Hermans and Broersma (2020) explored how news organizations experience innovation processes and how they can enhance a newsroom's resilience. The creative process is at the heart of innovation and requires skills as well as a specific understanding of the contexts in which it is applied (Küng, 2008), whether in the process of using social media as news sources (Von-Nordheim; Boczek; Koppers, 2018) or other journalistic practices.

As newsrooms adapt to editorial models and audience demands, new professional roles emerge. There is a growing need for 'adaptative journalists' open to experimentation in multidisciplinary teams where collaboration between journalists and technologists is commonplace (Palomo; Palau-Sampio, 2016), such as innovative fact-checking units (Graves; Nyhan; Reifler, 2016), web analytics (Lamot; Paulussen, 2020) and data journalists (Appelgren; Nygren, 2014; De-Maeyer et al., 2015; Zhang; Feng, 2019). One of the great deterrents to the development of data journalism in small newsrooms is the consideration of this specialty as a 'ghetto' (Arias-Robles; López-López, 2020). According to this view,

"innovation, aesthetics or the opinion of the specialists is often more important in data journalism than the true effects and profitability of the contents" (p. 7).

Media companies are hiring professionals with backgrounds in computing, engineering, and statistics (Holton; Belair-Gagnon, 2018). These 'strangers' to journalism shape news production and

"may have different levels of influence on journalistic norms and practices based on the innovations they adopt and their positions within professional journalism" (Holton; Belair-Gagnon, 2018, p. 76).

The role of some departments, such as web analytics, might be controversial in some instances (Belair-Gagnon; Holton, 2019). Journalists and technologists also collaborate through organizations such as Hacks/Hackers (Lewis; Usher, 2014).

In computer-based events (journalism hackathons), participants create product prototypes, enabling institutional stakeholders and the public to collaborate. In some instances, journalism hackathons operate as a community-based laboratory for translating open data from practitioners to the public (Boyles, 2017).

Gynnild (2014a) alludes to the liquid boundaries between journalists and programmers, pointing out

"the need for an innovative mindset amongst all news professionals" (p. 727). 
She found that computational exploration that challenges the traditional ideas of journalism also triggers innovative thinking and behavior among the actors themselves. According to Lewis and Usher (2016), programmers play a prominent role in newsrooms, where they incorporate skills that promote hacking, openness, and transparency,

"understanding journalism not as journalists but as intelligent consumers of information" (p. 14).

Therefore, innovation research should consider the complexity of intertwined contextual features, the intersection of news and technology, and the changing professional context (Konow-Lund; Hågvar; Olsson, 2019).

\section{Beyond traditional business models}

Researchers have increasingly explored how media organizations can develop revenue models beyond traditional income sources and how funding for high-quality journalism might be secured in a time of increasing uncertainty (Villi; Picard, 2018). The Covid-19 pandemic has deepened the economic crisis and alerted publishers to the urgent need to diversify sources of income and to seek new models. In this context, business model innovation has become consolidated as a promising field to promote value and to create, or retain, competitive advantage in the media sector (Evens; Raats; Von-Rimscha, 2017). However, in their exhaustive review of business model innovation research, Foss and Saebi (2017, p. 221) conclude that

"the literature is characterized by conceptual ambiguity and disconnected research efforts."

Research has focused on alternative revenue models, including paywalls (Arrese, 2015; Sjøvaag; Krumsvik, 2018), micropayments (Graybeal; Hayes, 2011), business alliances (De-Lara-González; Santos-Maestre, 2019; Mütterlein; Kunz, 2017), users' personal data (Bechmann; Bilgrav-Nielsen; Jensen, 2016), customization, resource development, and dialogue-based marketing communication (Cestino; Berndt, 2017), customer relationships (Barland, 2013), public funding for local journalism (Stonbely; Weber; Satullo, 2020) and crowdfunding (Carvajal; García-Avilés; González, 2012). In addition, researchers have also studied the role of audience participation in business models (Pettersen; Krumsvik, 2019), commercial strategies for online and multiplatform distribution (Doyle, 2013), and the use of external sources of financial aid, such as Google's Digital News Fund initiatives (Nunes; Canavilhas, 2020) or the Knight News Challenge grant-funding contest (Lewis, 2012; 2014). Studies have also discussed the role of media entrepreneurs in promoting innovative business models (Casero-Ripollés; Cullell-March, 2013; Compaine; Hoag, 2012). In this regard, Küng (2015, p. ix) examines the success of key players in digital news and highlights the "extremely coherent elements" of their successful business models.

It should not be overlooked that journalism is already underfunded from a welfare economy perspective, and this problem cannot be remedied by innovation alone. Nevertheless, a carefully designed and evidence-based innovation policy is a potentially powerful instrument to increase the journalistic and economic performance of news organizations and to ensure their sustainability. Günzel and Holm (2013) found that although most media companies have innovated in certain elements of their business models, innovation approaches often remain uncoordinated. According to Lehtisaari et al. (2018), newspaper companies

"have not been very innovative when it comes to media production, business models, sources of funding, new models for content distribution" (p. 1038).

Cestino and Matthews (2016) analyzed the persistence of the newspaper business model and stress that 'path un-locking' entails innovation in an organization's value creation logic. Wikström and Ellonen (2012) claim that media organizations have failed to restructure their business models and develop new capabilities to deal with social media platforms. Business model experimentation can be helpful to organizations considering opening and establishing the required linkages, e.g., technologies or social innovations that call for business solutions, experiments with alternative revenue sources and collecting additional customer data (Holm; Günzel; Ulhøi, 2013).

Recent research has examined innovative business models developed in Great Britain (Nel, 2010), Finland (Lindén, 2015), Norway (Sjøvaag; Krumsvik, 2018), Brazil (Capoano, 2018; Vieira-de-Araújo, 2019), United States (Villi et al., 2019), Scandinavia and the US (Lehtisaari et al., 2018) and Spain, where studies have analyzed sport news outlets (Manfredi-Sánchez; Rojas-Torrijos; Herranz-de-la-Casa, 2015) and the relationship between commercialization and organization (García-Santamaría; Clemente-Fernández; López-Aboal, 2013). Studies on journalism economics and innovation in geographical areas such as Latin-America (Harlow; Salaverría, 2016; Salaverría et al., 2019; Schmitz-Weiss et al., 2018), Central America (Harlow, 2018), and Africa (Paterson, 2019) reveal a promising field of research.

\section{Genre and content innovation}

Innovation in media narratives has not received as much attention as other fields, such as technology, management, organization, or commercialization. Practitioners argue that innovation should not exclusively be based on production technology but also include news genres and storytelling (García-Avilés; Carvajal; Comín, 2016, p. 187). A genre is considered innovative if it becomes an efficient way of designing content adapted to the story, thereby achieving success in terms of audience, advertising revenue, brand image or prestige for the outlet (García-Avilés, 2020a). News organizations are launching innovative online genres that allow the exploration of creative possibilities through different 
storytelling techniques and investigative methods (Konow-Lund, 2020) that sometimes help to connect with younger audiences (Emde; Klimmt; Schluetz, 2016).

Narrative innovations are rooted in the use of expressive resources, amplifying long-form explanations and the ability to connect with digital audiences, and maximizing the interactive, hypertextual and immersive possibilities of the medium (Røe-Mathisen; Morlandst $\varnothing, 2018)$. For instance, media organizations are increasingly experimenting and innovating in niche areas, such as sports journalism (Rojas-Torrijos, 2013; 2014), hyperlocal and community news (Harlow; Chadha, 2018; Heckman; Wihbey, 2019; Van-Kerkhoven, Bakker, 2014), political journalism (Brookes, 2018), or in the fight against hoaxes and misinformation (Valarezo-Cambizaca; Rodríguez-Hidalgo, 2019). Researchers have also investigated how innovation is implemented in journalists' blogs (Mitchelstein; Boczkowski; Wagner, 2017), newsletters (Hendrickx; Donders; Picone, 2020; Rojas-Torrijos; González-Alba, 2018), the use of links in hypertext (Arias-Robles; García-Avilés, 2017), and op-eds pages (Socolow, 2010).

\section{News organizations are launching inno- vative online genres that allow the ex- ploration of creative possibilities throu- gh different storytelling techniques and investigative methods}

Research on innovation in news narratives has proliferated, with studies that focus on genres produced for mobile devices (Palacios et al., 2016), storytelling in the visualization of information and data journalism (Appelgren; Nygren, 2014; Engebretsen; Kennedy; Weber, 2018), journalistic genres in Twitter, Instagram and other social media platforms (Chadha; Wells, 2016; García-Avilés; Arias-Robles, 2016b; Rojas-Torrijos; Panal-Prior, 2017), transmedia narratives (Peñafiel-Sáiz, 2016; Trillo-Domínguez; Alberich-Pascual, 2020), multimedia long-form stories (Ritter-Longhi; Flores, 2017; Vázquez-Herrero; Negreira-Rey; López-García, 2019), interactive documentaries or docuwebs (Parra-Valcarce; Martínez-Arias, 2019; Vázquez-Herrero; Negreira-Rey; Pereira-Fariña, 2017) and newsgames, which use game-based mechanics and playful thinking to promote learning about events through users' interaction (García-Ortega; García-Avilés, 2018; Plewe; Fürsich, 2020) and can add a potentially more powerful meaning to news (Dowling, 2020).

Innovations have been examined in long-form pieces that incorporate a creative use of audio in podcasts (Menduni, 2007), the production of immersive 360 o video, which allows the user to experience and be directly involved with the subject matter (Benítez-de-Gracia; Herrera-Damas, 2018; Lajqi; Lischka, 2020), broadcasting live streaming tools that engage with audiences in newscasts (Mancebo-García, 2016), online genres which combine stories for social media, web and television (García-Avilés, 2020a), investment in online video news (Kalogeropoulos; Nielsen, 2018), YouTube as a news dissemination channel (Santín; Álvarez-Monzoncillo, 2020), interactive infographics and visual representations (Toural-Bran et al., 2020), immersive virtual reality reports (Mabrook; Singer, 2019) and augmented reality in online news (Meneses-Fernández; Martín-Gutiérrez, 2013).

In short, as can be seen in this compilation of innovation studies, it is a fascinating scenario which continues to grow and diversify. In addition, users often become prosumers who participate in the creation of content and get involved in immersive experiences (Pérez-Seijo; Benítez-de-Gracia, 2018). As users' needs and preferences evolve, broadcasters must adapt and develop storytelling formats, distribution channels, business models and users' opportunities to interact with content (García-Avilés, 2020a; Owens; Dillman-Carpentier, 2004; Puijk, 2015). As Mabrook and Singer (2019, p. 2100) put it,

"the time is ripe for journalism studies scholars to engage with the implications of this immersive, multi-faceted, and emotionally compelling innovation for the product and practice of journalism."

A key challenge, nevertheless, is to make content relevant and useful for users without compromising the values of truthfulness, transparency, and credibility.

\section{Technological innovations and tools}

Continuous changes in communication technologies have significantly altered the practice of journalism, transforming the way news is gathered, produced, and disseminated (Pavlik, 2013). The intersections between technology and journalism are negotiated by actors engineering technological innovations and implementing them in the newsroom (Slaček-Brlek; Smrke; Vobič, 2017). Media companies often fail to successfully adopt emergent technology-driven media innovations due to organizational barriers (Zabel; Telkmann, 2020). Journalists and technical experts work more closely with one another through open-source engagement, which fosters such values as transparency, tinkering, iteration, and participation (Lewis; Usher, 2013).

Technologies have facilitated the implementation of innovative products, services and processes that meet users' needs (Storsul; Krumsvik, 2013). Koivula, Villi and Sivunen (2020) investigated how communication technology in creative work and innovation in journalistic teams plays a multi-dimensional role which is full of tensions. In the face of the complex challenges in a post Covid-19 world, there is a growing need for fact-checking (Graves; Nyhan; Reifler, 2016) and news investigation based on artificial intelligence that enhances journalists' abilities in investigative reporting (Broussard, 2015). 
The concept of computational journalism refers to systems that automate part of the content creation, production, and personalization of journalistic processes (Vállez; Codina, 2018). It is closely related to the concepts of 'algorithm journalism' (Lindén, 2017), 'robot journalism', and 'automated journalism' (Carlson, 2015), which simplify the work of humans by concentrating on mechanical tasks and processing large amounts of data (Gynnild, 2014a). News organizations are increasingly seeking to make sense of and derive value from Big Data by combining the use of algorithms, computation, and the quantification of massive volumes of data (Van-Dalen, 2012). As Lewis and Westlund (2015, p. 449) argue,

"Big data embodies emerging ideas about, activities for, and norms connected with data sets, algorithms, computational methods, and related processes and perspectives tied to quantification as a key paradigm of information work."

Other tasks for automated journalism include web and search engine optimization, online analytics, and content curation (Vállez; Codina, 2018). Algorithms can increase efficiency and job satisfaction with the automation of monotonous and routine tasks, as well as new forms of work 'yet-to-be-invented' that require computational thinking (Lindén, 2017, p. 61).

The emergence of drone journalism might exemplify a disruptive innovation in existing concepts of visual journalism that contributes to the creation of new genres, markets, and value networks (Belair-Gagnon; Owen; Holton, 2017; Gynnild, 2014b; Prudkin; Mielniczuk, 2019). Tools such as chatbots or conversational applications, based on artificial intelligence and instant messaging systems, can send filtered and personalized information to users (Belair-Gagnon; Lewis; Agur, 2020; Sánchez-Gonzales; Sánchez-González, 2017). Sketching is a technique that also develops business skills and fosters creative thinking about how journalism might evolve in light of emerging technologies (Doherty; Worthy, 2020). Media innovations related to the discipline of voice-user interface design and human-computer interaction enable users to interact through spoken commands and access to news content (Humphry; Chesher, 2020).

The changes associated with the implementation of digital technologies and tools have not only impacted on news products but also have organizational and institutional implications both for producers and users (Boczkowski, 2004; Küng, 2015). On the one hand, technology facilitates communication, creativity, and innovation in dispersed teams; on the other, it also leads to uncertainty in creative work (Koivula; Villi; Sivunen, 2020). Technologies such as algorithms, chatbots and automation bring about tangible newness and their novelty naturally generates excitement. However, technological advances in themselves are not innovations. Meaningful innovation in journalism must create news products that are genuinely useful to journalists, organizations, and users, providing them added value.

\section{Innovations in audience participation}

Although the integration of audience participation into the media innovation discourse has been limited, it has displaced the traditional communication paradigm in which the boundaries between senders and recipients were fixed, as individuals are perceived as subjects of the conversation and not just as passive receivers (Peña-Fernández et al. 2019). Participatory technologies have transformed the way in which citizens interact with the media, institutions, commerce, and culture. The spread of mobile devices and software make it easier for audiences to archive, comment on and rewrite media content, as well as distribute it. Web 2.0 tools have allowed individuals to easily create and disseminate contents that compete with media-produced news (Yeo, 2016). The participatory culture has been driven by the proliferation of social media platforms, which have become a field of experimentation and innovation for news organizations (Wu, 2019). Users are able to comment on and give feedback about the news (Zamith; Lewis, 2014) and are increasingly involved in innovative practices and processes, such as the creation of citizen-generated news photo agencies (Nicey, 2013), collaborative photojournalism (Gorin, 2015), or communicative interactions through Google Glass (Mills; Pellanda; Pase, 2017).

Heikka and Carayannis (2019) argue that a narrow understanding of the process of co-creation has limited both the practice and analysis of collaboration between audiences and professional journalists. Innovation in the public sphere can increase through the collaborative steps of co-initiating, co-sensing, and co-creating news (Heikka; Carayannis, 2019). Furthermore, both authors suggest that professional journalists should participate in the co-creation of journalism initiated by the civil society, challenging the conventional model of newsroom-led participatory journalism.

Many broadcasters, in response to the challenges of digitalization, transformation and adaptation to the new communication ecology, are innovating in strategies of audience participation (García-Perdomo, 2020). However, in the case of European public broadcasters, the management of their users' communities is still incipient, not very proactive, and highly conditioned by the demands of their parent public organizations (López-Golán; Rodríguez-Castro; Campos-Freire, 2019; Virta; Lowe, 2016). Nevertheless, Martínez-Fernández et al. (2018) found that some Eu-
Meaningful innovation in journalism must create news products that are genuinely useful to journalists, organizations, and users, providing them added value 
ropean broadcasters exhibited a highly personalized and segmented focus on the different audience sectors, as well as transparency in their policies.

In this regard, Franquet and Villa-Montoya (2014) emphasize an increase in audience loyalty in cross-participation initiatives implemented by the Spanish public broadcaster RTVE. Broadcast news innovation requires a multidisciplinary approach to connect with the needs of the public because audiences change even more than technologies and are the heart of innovation processes (Ranaivoson; Farchy; Gansemer, 2013; Virta; Lowe, 2016). Indeed, the process of reinventing Public Service Media could be enhanced through repositioning the innovation rationale. In some cases, such as in Flanders, public service broadcasters are receiving less investment in innovation (Donders et al., 2012). Cunningham (2015) shows the ways in which public service media can provide innovative products and services for viewers and for the media systems in which they operate.

\section{Both RTVE Lab and El Confidencial.LAB have implemented innovation strategies in key areas that provide them with a competitive advantage}

\section{The debate over media labs}

Innovation labs are a phenomenon worth noting. According to industry data, more than 30 laboratories operate in news organizations around the world, mostly in Europe and North America (García-Avilés, 2018). Prestigious news organizations such as The Washington Post, Le Monde, the BBC, AJ+ or The Guardian have implemented laboratories dedicated to producing innovative products, genres, and technological tools (López-Hidalgo; Ufarte-Ruiz, 2016). Although these departments do not necessarily in themselves imply the existence of innovation in the company, they do allow experimentation with content, product, technologies, and other elements. According to Sádaba-Chalezquer and Salaverría (2016, p. 153), a media laboratory's mission is

"to devise and promote innovations of a technological, editorial and/or commercial nature for the competitive improvement of the news organization."

Salaverría (2015) distinguishes four laboratory models: a) those focused on the development of technologies and apps; b) those oriented at innovation in languages, formats, infographics, and data journalism; c) those promoting business and commercial projects; and d) those devoted to training in journalism.

Media labs seem an ideal setting to try out formulas that could potentially add value and improve existing journalistic models (López-García; Silva-Rodríguez; Negreira-Rey, 2019, p. 157). Experimentation is essential in these laboratories, where professionals work in an adaptive culture which makes it easy to reject options that do not work and focus on the most viable ones (Carrión; Coronel-Salas, 2019). The innovative culture is also based on continuous learning, trial and error, minimum viable products, and the implementation of agile work methods (Pozo-Montes; Larrondo-Ureta, 2020). For instance, targeting a mobile-centric generation of social media users and tech-savvy youth, Al Jazeera's media lab for digital storytelling, launched in 2013 as part of its innovation division, seeks to engage audiences on a wide range of social media platforms (Zayani, 2020).

In Spain, digital-only El Confidencial.LAB is committed to a strategy based on innovation in key areas of journalistic activity, namely product, audiences, technology, organization, and sources of income (García-Avilés, 2018; Vara-Miguel, 2016). The lab is made up of interdisciplinary and autonomous teams dedicated to developing products, increasing the organization's flexibility, and improving user experience. In addition, a number of European Public Service Media have launched labs devoted to the implementation of products, services, and formats for multiplatform audiences. BBC News Labs develops a global innovation strategy through the design and engineering of products that facilitate journalists' work (Zaragoza-Fuster; García-Avilés, 2020). Projects include speech-to-text software, prototypes for voice recognition and text analysis, chatbots and object-based media. Spain's RTVE Lab focuses on designing and producing interactive genres, multimedia narratives and social media content, with an emphasis on experimentation (Arias-Robles, 2016; Zaragoza-Fuster; García-Avilés, 2018). Both RTVE Lab and ElConfidencial.LAB have implemented a strategy based on innovation in key areas, which gives them a competitive advantage (García-Avilés, 2020c).

Innovation labs can also present some serious challenges for media companies. This happens when lab teams focus their attention on making new products without thinking about the business models that underlie those products, or when they become frustrated when scaling up innovative products and are faced with resistance from their parent company (García-Avilés; Arias-Robles, 2018). Isolation can also become a major obstacle to efficiency and innovation when these labs work in isolation from the main newsroom or when little knowledge transfer occurs (Valero-Pastor; Carvajal-Prieto, 2019). The risk of media labs becoming 'innovation silos' with few consequences for the rest of the news organization has been pointed out, as they appear to insulate collaborative teams from the culture of the larger newsroom (Boyle, 2016).

While these in-house innovation units are intended to infuse experimentation and creativity across the newsroom, institutional barriers hinder their success. According to Boyle (2016, p. 241), 
"the organizational hierarchy often acts to constrain the innovative work of intrapreneurial units within digital newsrooms. In the executive layer, newsroom management appears rigid, governed by top-down imperatives issued through formalized channels."

As Boyle argues, journalistic autonomy and diffusion of innovations involves three fundamental shifts: from standalone media organizations to networks and alliances; from isolated to harmonized laboratories; and from inward-looking institutional preoccupations to harnessing global flows of experiences, resources, and innovations.

\section{News start-ups and their impact on the media ecosystem}

A growing body of research explores the role of start-ups as new actors in the digital media scenario, which tend to incorporate agile, flexible work processes, open mindedness, and multidisciplinary work teams (Nee, 2013; Van-Weezel, 2010). In an exploratory study, McKelvie and Wiklund (2008) show that knowledge acquisition practices of new and young media outlets were the largest explanatory factors for both product and customer innovation. Most studies reflect an optimistic view of the trend, which is perceived as a hopeful response in the face of the decline of traditional journalism and its economic models (Valero-Pastor; González-Alba, 2018). These authors recognize the transformative power of start-ups, which can help established media to reformulate their hypotheses and adapt to the new market paradigms, thus providing greater flexibility to the entire industry. Carlson and Usher (2016, p. 2) argue, in their study on the meta-discourse of these companies

A key factor that provides media startups a privileged position to innovate is flexibility through their foundational manifestos, that start-ups

"compete to define how digital news should be, re-establish the limits of journalism and determine strategies to legitimize their contents."

A key factor that provides media start-ups a privileged position to innovate is flexibility. These companies operate with small structures, constantly evolving and lacking rigid boundaries, which allows them to better adapt to an unpredictable market. Flexibility translates, for example, into minimal staff, multidisciplinary teamwork, and the absence of physical newsrooms (García-Avilés et al., 2016, p. 221). Start-ups seek to compete in terms of being

"more innovative and more in tune with the needs of the public than the big news companies and the legacy media" (Prenger; Deuze, 2017, p. 249).

Sommer (2018) shows that start-ups generate market intelligence in various ways and, in doing so, prioritize their efforts to learning about users, while paying less attention on examining businesses and competitors. Overall, market orientation seems to have a positive influence on news start-ups' survival and support innovation (Sommer, 2018, p. 46). Many start-ups try to fit into a niche and not compete with legacy media, and search for alternative financing sources (Crespo et al., 2020; Slot, 2018). Digital news start-ups with solid foundations, clear objectives, and well-designed strategies have an excellent chance of carving out a niche in the current marketplace.

News entrepreneurism is considered a potential force to revitalize digital journalism (Carlson; Usher, 2016) and to increase innovative practices in media companies (Nee, 2013). News entrepreneurs are regarded as 'agents of innovation' (Carlson; Usher, 2016, p. 563), challenging the traditional concepts of journalism and retaining the underlying principles of the profession (Usher, 2017). Digital-only news outlets are perceived as laboratories for innovation and as trendsetters, and even their failures can provide useful lessons for the media industry (Buschow, 2020). Entrepreneurial news ventures have driven innovation by organizing themselves as cooperatives, developing successful reader membership schemes and promoting synergies that underline the added value of collaboration (Powers; Vera-Zambrano, 2016; Siapera; Papadopoulou, 2016). Harlow and Chadha's (2019) study on digital news startups in India suggests that social identity is tied to understandings of innovation, financing, experimentation, audience interaction, and mission. Thus, entrepreneurial journalism is contributing to the development of models for news production, distribution and commercialization (Mendiguren-Galdospin; Agirreazkuenaga-Onaindia; Meso-Ayerdi, 2019; Zhang, 2019).

The interaction at the intersection of legacy news organizations and start-up digital media companies has created new opportunities for innovation. Venture capital funding as a resource promotes innovation from outside the media ecosystem (Kosterich; Weber, 2018; Usher, 2017). News start-ups aim to solve what they regard as journalistic problems in novel ways, yet their concerns mirror larger historical critiques of the profession and the industry (Prenger; Deuze, 2017). However, the tensions between commercial media and publicly financed news outlets are regarded as obstacles to an open approach to innovation (Slot, 2018). Their distinct technological and cultural innovations -the creation of news personalization tools, the development of scalable technology, and the elevation of technological innovation and technologists as equal to journalists-
Researchers interested in media transformation processes should explore which research objects can be labelled as 'innovations' and holistically integrate different perspectives and methodologies 
"do prompt consideration about how the underlying habitus of journalists may well be challenged" (Usher, 2017, p. 1116).

\section{Conclusion and suggestions for further research}

Research on journalism innovation has grown considerably over the last two decades, especially in the areas of management, diffusion, organizational culture, technology, and business models. However, researchers could broaden their interests to deal with issues related to professional culture, as technological tools, economic conditions, and organizational structures continue to transform journalism; interdisciplinary project management, team coordination, and knowledge transfer; leadership and effectiveness; sources of influence, innovation, and creativity; organizational decision-making processes and constraints; innovative professional practices and their influence on journalistic standards and values. These subjects provide a fertile landscape for researchers in journalism innovation to explore.

There is a need for further research to gain deeper insight into the nature, conceptualization, and effects of journalistic innovation. Researchers interested in media transformation processes should explore which research objects can be labelled as 'innovations' and holistically integrate different perspectives and methodologies. Research regarding innovations' social implications and their consequences in organizations is growing but still an immature field. By pursuing integrative perspectives, academics can strive for new theoretical thinking that expands diffusion theory to consider the challenges associated with big data and artificial intelligence, disruptive players such as technological companies, as well as the changing policy environment.

Methodological proposals for future research are also encouraged. It is necessary to expand the traditional methods of case studies and interviews. Longitudinal investigations should be carried out over periods of time, beyond the analysis of the situation at a specific moment, considering the broader factors that influence the development of journalistic innovation at the macro, mezzo, and micro levels. Furthermore, there is a need for comparative studies of an international nature that shed light on innovation in diverse contexts and markets. A key challenge is to move beyond the models of the past and to address the implications of Diffusion of Innovation theory, as news organizations that operate in open media ecosystems are able to grow, absorb new entities, adapt, react, and transform themselves.

The Covid-19 pandemic is speeding up the process of media transformation. The model of journalism financed mainly through advertising is coming to an end and news organizations have a pressing need to diversify their sources of income. The Covid-19 crisis has exposed people's media-related practices and helped to understand the reasons why they engage with the news with a public service journalism focus, providing an opportunity for innovation (Hess; Waller, 2020 b). A key issue is not how newsrooms can innovate in the interests of their own viability but rather how they can build relevance in the interests of the public that they serve. However, innovation can only provide a partial answer to the current challenges news organizations are currently facing.

Longitudinal investigations should be carried out over periods of time, beyond the analysis of the situation at a specific moment

\section{References}

Adornato, Anthony C. (2014). “A digital juggling act: New media's impact on the responsibilities of local television reporters". Electronic news, v. 8, n. 1, pp. 3-29.

https://doi.org/10.1177/1931243114523963

Aitamurto, Tanja; Lewis, Seth C. (2013). "Open innovation in digital journalism: Examining the impact of open APIs at four news organizations". New media \& society, v. 15, n. 2, pp. 314-331.

https://doi.org/10.1177/1461444812450682

Appelgren, Ester; Nygren, Gunnar (2014). “Data journalism in Sweden: Introducing new methods and genres of journalism into 'old' organizations". Digital journalism, v. 2, n. 3, pp. 394-405.

https://doi.org/10.1080/21670811.2014.884344

Appelgren, Esther; Nygren, Gunnar (2019). “HiPPOs (highest paid person's opinion) in the Swedish media industry on innovation: A study of news media leaders' attitudes towards innovation". The journal of media innovations, v. 5, n. 1, pp. $45-60$.

https://doi.org/10.5617/jomi.6503

Arias-Robles, Félix (2016). "RTVE y RTVE Lab: incubadora de innovación”. In: Sádaba-Chalezquer, Charo; García-Avilés, José-Alberto; Martínez-Costa, María-Pilar (coords.). Innovación y desarrollo de los cibermedios en España. Eunsa: Pamplona, pp. 20-25. ISBN: 9788431331252

Arias-Robles, Félix; García-Avilés, José-Alberto (2017). “Many short links: The influence of the quantity and size of links on user behaviour, perception and comprehension". Digital journalism, v. 5, n. 9, pp. 1205-1225.

https://doi.org/10.1080/21670811.2016.1240014 
Arias-Robles, Félix; López-López, Pilar-José (2020). “Driving the closest information. Local data journalism in the UK”. Journalism practice, online first.

https://doi.org/10.1080/17512786.2020.1749109

Arrese, Ángel (2016). "From gratis to paywalls: A brief history of a retro-innovation in the press's business". Journalism studies, v. 17, n. 8, pp. 1051-1067.

https://doi.org/10.1080/1461670X.2015.1027788

Ashuri, Tamar (2013). "Envisioning the Internet: Implementing 'disruptive innovation' in media organizations". First Monday, v. 18, n. 5.

https://firstmonday.org/ojs/index.php/fm/article/download/4216/3668

Atkin, David J.; Hunt, Daniel S.; Lin, Carolyn A. (2015). "Diffusion theory in the new media environment: Toward an integrated technology adoption model". Mass communication and society, v. 18, n. 5, pp. 623-650.

https://doi.org/10.1080/15205436.2015.1066014

Badillo, Patrick-Yves; Bourgeois, Dominique (2020). "Innovation and media: googlization and limited creativity". In: Kiriya, Ilya; Kompatsiaris, Panos; Mylonas, Yannis (eds.). The industrialization of creativity and its limits. Values, politics and lifestyles of contemporary cultural economies, pp. 189-204. ISBN: 9783030531638

Bakker, Piet (2013). "Measuring innovation. Successes and failures in a newspaper market". In: Storsul, Tanja; Krumsvik, Arne H. (eds.). Media innovations. A multidisciplinary study of change. Göteborg: Nordicom, pp. 161-174. ISBN: 97891 86523657

Barland, Jens (2013). "Innovation of new revenue streams in digital media. Journalism as customer relationship". Nordicom review, n. 34, pp. 99-112.

https://www.nordicom.gu.se/en/node/34528

Barnhurst, Kevin G. (2012). "'Trust me, I'm an innovative journalist,' and other fictions". In: Broersma, Marcel; Peters, Chris (eds.). Rethinking journalism: trust and participation in a transforming media landscape. London: Routledge, pp. 210-220. ISBN: 9780415697019

Baumann, Sabine (2013). "Adapting to the brave new world. Innovative organisational strategies for media companies". In: Storsul, Tanja; Krumsvik, Arne H. (eds.). Media innovations. A multidisciplinary study of change. Göteborg: Nordicom, pp. 77-92. ISBN: 9789186523657

Bechmann, Anja; Bilgrav-Nielsen, Kristine; Korsgaard-Jensen, Anne-Louise (2016). "Data as a revenue model: Sharewall as a payment method and editorial algorithm in the news industry". Nordicom information, v. 38, n. 1, pp. 76-82. https://www.nordicom.gu.se/en/node/37011

Belair-Gagnon, Valerie; Holton, Avery E. (2019). "The two faces of Janus: Web analytics companies and the shifting culture of news". Journalism practice, v. 13, n. 8, pp. 993-997.

https://doi.org/10.1080/17512786.2019.1642132

Belair-Gagnon, Valerie; Lewis, Seth C.; Agur, Colin (2020). "Failure to launch: competing institutional logics, intrapreneurship, and the case of chatbots". Journal of computer-mediated communication, v. 25, n. 4, pp. 291-306. https://doi.org/10.1093/jcmc/zmaa008

Belair-Gagnon, Valerie; Owen, Taylor; Holton, Avery E. (2017). "Unmanned aerial vehicles and journalistic disruption: Perspectives of early professional adopters". Digital journalism, v. 5, n. 10, pp. 1226-1239. https://doi.org/10.1080/21670811.2017.1279019

Belair-Gagnon, Valerie; Steinke, Allison J. (2020). “Capturing digital news innovation research in organizations, 19902018". Journalism studies, v. 21, n. 12, pp. 1724-1743.

https://doi.org/10.1080/1461670X.2020.1789496

Benítez-de-Gracia, María-José; Herrera-Damas, Susana (2018). “El reportaje inmersivo en vídeo 360o: diseño de un modelo de análisis". El profesional de la información, v. 27, n. 1, pp. 149-161.

https://doi.org/10.3145/epi.2018.ene.14

Bleyen, Válery-Anne; Lindmark, Sven; Ranaivoson, Heritiana; Ballon, Pieter (2014). "A typology of media innovations: Insights from an exploratory study". The journal of media innovations, v. 1, n. 1, pp. 28-51.

https://doi.org/10.5617/jmi.v1i1.800

Boczkowski, Pablo J. (2004). Digitizing the news: Innovation in online newspapers. Cambridge, MA: MIT Press. ISBN: 0262025590

Boczkowski, Pablo J. (2004). "The mutual shaping of technology and society in videotex newspapers: Beyond the diffusion and social shaping perspectives". The information society, v. 20, n. 4, pp. 255-267.

https://doi.org/10.1080/01972240490480947 
Boczkowski, Pablo J.; Ferris, José-Antonio (2005). “Multiple media, convergent processes, and divergent products: Organizational innovation in digital media production at a European firm". The annals of the American Academy of Political and Social Science, v. 597, n. 1, pp. 32-47.

https://doi.org/10.1177/0002716204270067

Boyles, Jan-Lauren (2016). "The isolation of innovation: Restructuring the digital newsroom through intrapreneurship". Digital journalism, v. 4, n. 2, pp. 229-246.

https://doi.org/10.1080/21670811.2015.1022193

Boyles, Jan-Lauren (2020). "Laboratories for news? Experimenting with journalism hackathons". Journalism, v. 21, n. 9, pp. 1338-1354.

https://doi.org/10.1177/1464884917737213

Broersma, Marcel; Singer, Jane B. (2020). "Caught between innovation and tradition: young journalists as normative change agents in the journalistic field". Journalism practice, online first.

https://doi.org/10.1080/17512786.2020.1824125

Brookes, Stephanie (2018). “'Join us for all the developments': Guardian Australia and the construction of journalistic identity in press gallery reporting". Media international Australia, v. 167, n. 1, pp. 105-120.

https://doi.org/10.1177/1329878X18766079

Broussard, Meredith (2015). "Artificial intelligence for investigative reporting: Using an expert system to enhance journalists' ability to discover original public affairs stories". Digital journalism, v. 3, n. 6, pp. 814-831.

https://doi.org/10.1080/21670811.2014.985497

Bruns, Axel (2014). "Media innovations, user innovations, societal innovations". The journal of media innovations, v. 1, n. 1, pp. 13-27.

https://doi.org/10.5617/jmi.v1i1.827

Buschow, Christopher (2020). "Why do digital native news media fail? An investigation of failure in the early start-up phase". Media and communication, v. 8, n. 2, pp. 51-61.

https://doi.org/10.17645/mac.v8i2.2677

Capoano, Edson (2018). "Innovación en medios independientes digitales: casos en Brasil y España”. Mediatika. Cuadernos de medios de comunicación, n. 16.

http://ojs.eusko-ikaskuntza.eus/index.php/mediatika/article/view/149

Carlson, Matt (2015). "The robotic reporter: Automated journalism and the redefinition of labor, compositional forms, and journalistic authority". Digital journalism, v. 3, n. 3, pp. 416-431.

https://doi.org/10.1080/21670811.2014.976412

Carlson, Matt; Usher, Nikki (2016). "News startups as agents of innovation. For-profit digital news startup manifestos as metajournalistic discourse". Digital journalism, v. 4, n. 5, pp. 563-581.

https://doi.org/10.1080/21670811.2015.1076344

Carvajal-Prieto, Miguel; Arias-Robles, Félix; Negredo, Samuel; Amoedo, Avelino (2015). “Aproximación metodológica al estudio de la innovación en periodismo". Observatorio (OBS*), v. 9, n. 3, pp. 15-31.

http://obs.obercom.pt/index.php/obs/article/view/793

Carvajal-Prieto, Miguel; García-Avilés, José-Alberto; González, José-Luis (2012). “Crowdfunding and non-profit media: The emergence of new models for public interest journalism". Journalism practice, v. 6, n. 5-6, pp. 638-647.

https://doi.org/10.1080/17512786.2012.667267

Casero-Ripollés, Andreu; Cullell-March, Cristina (2013). "Periodismo emprendedor. Estrategias para incentivar el autoempleo periodístico como modelo de negocio". Estudios sobre el mensaje periodístico, v. 19, pp. 681-690.

https://doi.org/10.5209/rev_ESMP.2013.v19.42151

Cestino, Joaquín; Berndt, Adele (2017). "Institutional limits to service dominant logic and servitisation in innovation efforts in newspapers". Journal of media business studies, v. 14, n. 3, pp. 188-216.

https://doi.org/10.1080/16522354.2018.1445163

Chadha, Kalyani; Wells, Rob (2016). "Journalistic responses to technological innovation in newsrooms: An exploratory study of Twitter use". Digital journalism, v. 4, n. 8, pp. 1020-1035.

https://doi.org/10.1080/21670811.2015.1123100

Chasi, Colin; Rodny-Gumede, Ylva (2020) “Innovation in communication and media studies: reflections from South African academics". Communicatio, v. 46, n. 2, pp. 107-125.

https://doi.org/10.1080/02500167.2020.1796728 
Chua, Sherwin; Duffy, Andrew (2019). “Friend, foe or frenemy? Traditional journalism actors' changing attitudes towards peripheral players and their innovations". Media and communication, v. 7, n. 4, pp. 112-122.

https://doi.org/10.17645/mac.v7i4.2275

Colussi, Juliana; Gomes-Franco-e-Silva, Flávia; Melani-Rocha, Paula (eds.). (2018). Periodismo ubicuo: convergencia e innovación en las nuevas redacciones. Bogotá: Editorial Universidad del Rosario. ISBN: 9789587840728

Compaine, Ben; Hoag, Anne (2012). "Factors supporting and hindering. New entry in media markets: A study of media entrepreneurs". International journal on media management, v. 14, n. 1, pp. 27-49.

https://doi.org/10.1080/14241277.2011.627520

Creech, Brian; Mendelson, Andrew L. (2015) "Imagining the journalist of the future: technological visions of journalism education and newswork". The communication review, v. 18, n. 2, pp. 142-165.

https://doi.org/10.1080/10714421.2015.1031998

Creech, Brian; Nadler, Anthony M. (2018). “Post-industrial fog: Reconsidering innovation in visions of journalism's future". Journalism, v. 19, n. 2, pp. 182-199.

https://doi.org/10.1177/1464884916689573

Crespo, Miguel; Pinto-Martinho, Ana; Foà, Caterina; Paisana, Miguel; Pais, Pedro-Caldeira (2020). "Business models of journalistic startups in Portugal: an analysis of product innovation, dissemination and monetization in media enterprises". Nordic journal of media management, v. 1, n. 2, pp. 261-296.

https://doi.org/10.5278/njmm.2597-0445.5194

Cunningham, Stuart (2015). "Repositioning the innovation rationale for public service media". International journal of digital television, v. 6, n. 2, pp. 203-220.

https://doi.org/10.1386/jdtv.6.2.203_1

Dal-Zotto, Cinzia; Van-Kranenburg, Hans (eds.) (2008). Management and innovation in the media industry. Cheltenham: Edward Elgar Publishing. ISBN: 9781847201096

De-Lara-González, Alicia; Arias-Robles, Félix; Carvajal-Prieto, Miguel; García-Avilés, José-Alberto (2015). “Ranking de innovación periodística 2014 en España. Selección y análisis de 25 iniciativas". El profesional de la información, v. 24, n. 3, pp. 235-245.

https://doi.org/10.3145/epi.2015.may.03

De-Lara-González, Alicia; Santos-Maestre, Lorena (2019). "Análisis de las relaciones entre medios de comunicación digitales: ejemplos del panorama español". Revista internacional de historia de la comunicación, n. 13, pp. 53-70.

https://doi.org/10.12795/RiHC.2019.i13.04

De-Maeyer, Juliette; Libert, Manon; Domingo, David; Heinderyckx, François; Le-Cam, Florence (2015). "Waiting for data journalism: A qualitative assessment of the anecdotal take-up of data journalism in French-speaking Belgium". Digital journalism, v. 3, n. 3, pp. 432-446.

https://doi.org/10.1080/21670811.2014.976415

Dogruel, Leyla (2013). “Opening the black box. The conceptualising of media innovation”. In: Storsul, Tanja; Krumsvik, Arne H. (eds.). Media innovations. A multidisciplinary study of change. Göteborg: Nordicom, pp. 29-44. ISBN: 97891 86523657

Dogruel, Leyla (2014). "What is so special about media innovations? A characterization of the field". The journal of media innovations, v. 1, n. 1, pp. 52-69.

https://doi.org/10.5617/jmi.v1i1.665

Dogruel, Leyla (2015). "Innovation research in media management and economics: An integrative framework". Journal of media business studies, v. 12, n. 3, pp. 153-167.

https://doi.org/10.1080/16522354.2015.1069478

Doherty, Skye; Worthy, Peter (2020). "Sketching: A method for imagining journalistic tech". Digital journalism, online first.

https://doi.org/10.1080/21670811.2020.1764373

Domingo, David (2008). "Interactivity in the daily routines of online newsrooms: Dealing with an uncomfortable myth". Journal of computer-mediated communication, v. 13, n. 3, pp. 680-704.

https://doi.org/10.1111/j.1083-6101.2008.00415.x

Donders, Karen; Ranaivoson, Heritiana; Lindmark, Sven; Ballon, Pieter (2012). "Public broadcasters and innovation: A contested combination in Flanders". Innovation, v. 14, n. 2, pp. 276-288.

https://doi.org/10.5172/impp.2012.14.2.276 
Dowling, David O. (2020). The gamification of digital journalism: innovation in journalistic storytelling. London: Routledge. ISBN: 9780367076252

Doyle, Gillian (2013). "Re-invention and survival: Newspapers in the era of digital multiplatform delivery". Journal of media business studies, v. 10, n. 4, pp. 1-20.

https://doi.org/10.1080/16522354.2013.11073569

Drok, Nico (2013). "Beacons of reliability: European journalism students and professionals on future qualifications for journalists". Journalism practice, v. 7, n. 2, pp. 145-162.

https://doi.org/10.1080/17512786.2012.753209

Ekdale, Brian; Singer, Jane B.; Tully, Melissa; Harmsen, Shawn (2015). "Making change: Diffusion of technological, relational, and cultural innovation in the newsroom". Journalism \& mass communication quarterly, v. 92, n. 4, pp. 938-958. https://doi.org/10.1177/1077699015596337

Emde, Katharina; Klimmt, Chistoph; Schluetz, Daniela M. (2016). “Does storytelling help adolescents to process the news? A comparison of narrative news and the inverted pyramid". Journalism studies, v. 17, n. 5, pp. 608-627. https://doi.org/10.1080/1461670X.2015.1006900

Engebretsen, Martin; Kennedy, Helen; Weber, Wibke (2018). "Data visualization in Scandinavian newsrooms: Emerging trends in journalistic visualization practices". Nordicom review, v. 39, n. 2, pp. 3-18.

https://doi.org/10.2478/nor-2018-0007

English, Peter (2016). "Twitter's diffusion in sports journalism: Role models, laggards and followers of the social media innovation". New media \& society, v. 18, n. 3, pp. 484-501.

https://doi.org/10.1177/1461444814544886

Evans, Sandra K. (2018). "Making sense of innovation: Process, product, and storytelling innovation in public service broadcasting organizations". Journalism studies, v. 19, n. 1, pp. 4-24.

https://doi.org/10.1080/1461670X.2016.1154446

Evens, Ton; Raats, Tim; Von-Rimscha, M. Bjørn (2017). “Business model innovation in news media organisations-2018 special issue of the European Media Management Association". Journal of media business studies, v. 14, n. 3, pp. 167172.

https://doi.org/10.1080/16522354.2018.1445164

Fernández-Quijada, David; Bonet, Montse; Suárez-Candel, Roberto; Arboledas, Luis (2015). "From rhetorics to practice: Implementation of technological innovation within Spanish public service media". The journal of media innovations, v. 2, p. 2, pp. 23-39.

https://doi.org/10.5617/jmi.v2i2.845

Ferrucci, Patrick (2018). "We've lost the basics": perceptions of journalism education from veterans in the field". Journalism \& mass communication educator, v. 73, n. 4, pp. 410-420.

https://doi.org/10.1177/1077695817731870

Foss, Nicolai J.; Saebi, Tina (2017). "Fifteen years of research on business model innovation: How far have we come, and where should we go?”. Journal of management, v. 43, n. 1, pp. 200-227.

https://doi.org/10.1177/0149206316675927

Franquet, Rosa; Villa-Montoya, María-Isabel (2014). “Cross-media production in Spain's public broadcaster RTVE: Innovation, promotion, and audience loyalty strategies". International journal of communication, v. 8, pp. 2301-2322.

https://ijoc.org/index.php/ijoc/article/viewFile/2621/1203

Gade, Peter J.; Perry, Earnest L. (2003). “Changing the newsroom culture: A four-year case study of organizational development at the St. Louis Post-dispatch". Journalism \& mass communication quarterly, v. 80, n. 2, pp. 327-347.

https://doi.org/10.1177/107769900308000207

Gade, Peter J.; Shugofa-Dastgeer, Christina; Childs-DeWalt, Emmanuel-Lugard-Nduka; Seunghyun-Kim, Desiree-Hill; Curran, Kevin (2018). “Management of journalism transparency: Journalists' perceptions of organizational leaders' management of an emerging professional norm". International journal on media management, v. 20, n. 3, pp. $157-173$. https://doi.org/10.1080/14241277.2018.1488257

García-Avilés, José-Alberto (2012). "Innovation management in crossmedia production: Leading change in the newsroom". In: Ibrus, Indrek; Scolari, Carlos A. (eds.). Crossmedia innovations: Texts, markets, institutions. Frankfurt: Peter Lang, pp. 220-239. ISBN: 9783631622285

García-Avilés, José-Alberto (2016). "Lo imposible: Construyendo la ética del periodismo tras el tsunami digital”. In: Suárez-Villegas, Juan-Carlos; Cruz-Álvarez, Jesús (eds.). Desafíos éticos en el periodismo digital. Madrid: Dykinson, pp. 29-49. ISBN: 9788490859780 
García-Avilés, José-Alberto (2017). “Identifying innovation. How to grasp the chance of change -some lessons from Spain”. In: Kaltenbrunner, Andy; Karmasin, Matthias; Kraus, Daniela (eds.). Journalism report V: Innovation and transition. Viena: Facultas, pp. 35-48. ISBN: 9783708915784

García-Avilés, José-Alberto (2018). "Resultados de la innovación en los laboratorios de medios: el caso de El confidencial.LAB". El profesional de la información, v. 27, n. 2, pp. 359-366.

https://doi.org/10.3145/epi.2018.mar.14

García-Avilés, José-Alberto (2020a). "Reinventing television news: Innovative formats in a social media environment". In: Vázquez-Herrero, Jorge; Direito-Rebollal, Sabela; Silva-Rodríguez, Alba; López-García, Xosé (eds.). Journalistic metamorphosis. Media transformation in the digital age. Cham, Springer, pp. 143-155. ISBN: 9783030363147

García-Avilés, José-Alberto (2020b). “Diffusion of innovation”. In: Van-den-Bulck, Jan (ed.). The international encyclopedia of media psychology. London: Wiley, pp. 1-8. ISBN: 9781119011064

García-Avilés, José-Alberto (2020c). "How news organizations face disruption in a networked environment: exploring the implementation of innovations in media labs". In: Peña-Fernández, Simón; Meso-Ayerdi, Koldobika; Larrondo-Ureta, Ainara (eds.). Active audiences. Empowering citizens' discourse in the hybrid media system. Madrid: McGraw Hill, pp. 55-66. ISBN: 9788448920059

García-Avilés, José-Alberto; Arias-Robles, Félix (2016a). “Evolución de los cibermedios en España: claves de la innovación”. In: Sádaba-Chalezquer, Charo; García-Avilés, José-Alberto; Martínez-Costa, María-Pilar (Coords.) Innovación y desarrollo de los cibermedios en España. Pamplona: Eunsa, pp. 63-71. ISBN: 9788431331252

García-Avilés, José-Alberto; Arias-Robles, Félix (2016b). "Géneros periodísticos en los formatos visuales de Twitter: una propuesta de tipología". Textual \& visual media, v. 9, pp. 101-132.

http://textualvisualmedia.com/index.php/txtvmedia/article/view/52/42

García-Avilés, José-Alberto; Arias-Robles, Félix (2018). “Análisis de innovaciones en el sector audiovisual: los casos de la productora 93Metros y el lab de RTVE". In: Rodríguez-Rodríguez, Jorge M. (coord.). Retroperiodismo, o el retorno a los principios de la profesión periodística. Zaragoza: Sociedad Española de Periodística, pp. 195-208. ISBN: 9788494494123

García-Avilés, José-Alberto; Carvajal-Prieto, Miguel; Arias-Robles, Félix (2018). “Implementation of innovation in Spanish digital media: analysis of journalists' perceptions”. Revista latina de comunicación social, n. 73, pp. 369 -384.

http://www.revistalatinacs.org/073paper/1260/19en.html

García-Avilés, José-Alberto; Carvajal-Prieto, Miguel; Arias-Robles, Félix; De-Lara-González, Alicia (2019). “How journalists innovate in the newsroom. Proposing a model of the diffusion of innovations in media outlets". The journal of media innovations, v. 5, n. 1, pp. 1-16.

https://doi.org/10.5617/jomi.v5i1.3968

García-Avilés, José-Alberto; Carvajal-Prieto, Miguel; Comín, María (eds.) (2016). Cómo innovar en periodismo. Entrevistas a 27 profesionales. Murcia: Diego Marín. ISBN: 9788416908394

García-Avilés, José-Alberto; Carvajal-Prieto, Miguel; De-Lara-González, Alicia; Arias-Robles, Félix (2018). “Developing an index of media innovation in a national market: The case of Spain". Journalism studies, v. 19, n. 1, pp. 25-42.

https://doi.org/10.1080/1461670X.2016.1161496

García-Avilés, José-Alberto; Martínez-Costa, María-Pilar; Sádaba-Chalezquer, Charo (2016). “Luces y sombras sobre la innovación en los medios españoles". In: Sádaba-Chalezquer, Charo; García-Avilés, José-Alberto; Martínez-Costa, María-Pilar (coords.). Innovación y desarrollo de los cibermedios en España. Eunsa: Pamplona, pp. 265-270. ISBN: 9788431331252

García-Avilés, José-Alberto; Meier, Klaus; Kaltenbrunner, Andy (2017) “Converged media content: reshaping the 'legacy' of legacy media in the online scenario". In: Franklin, Bob; Eldridge, Scott A. II (eds.). The Routledge companion to digital journalism studies. London: Routledge, pp. 449-458. ISBN: 9781138887961

García-Ortega, Alba; García-Avilés, José-Alberto (2018). “Los newsgames como estrategia narrativa en el periodismo transmedia: propuesta de un modelo de análisis”. Revista mediterránea de comunicación, v. 9, n. 1, pp. 327-346.

https://www.doi.org/10.14198/MEDCOM2018.9.1.19

García-Perdomo, Víctor (2020). “Re-digitizing television news: The relationship between TV, online media and audiences". Digital journalism, online first.

https://doi.org/10.1080/21670811.2020.1777179

García-Perdomo, Víctor; Magaña, María-Isabel (2020). "The adoption of technology and innovation among native online news media in Colombia". International journal of communication, v. 14, pp. 3076-3095.

https://ijoc.org/index.php/ijoc/article/view/12124 
García-Santamaría, José-Vicente; Clemente-Fernández, María-Dolores; López-Aboal, María (2013). “La organización de las redacciones en los nuevos diarios digitales españoles y su relación con los nuevos modelos de negocio". Textual and visual media, n. 6, pp. 141-160.

http://textualvisualmedia.com/index.php/txtvmedia/article/view/81

Garrison, Bruce (2001). "Diffusion of online information technologies in newspaper newsrooms". Journalism, v. 2, n. 2, pp. 221-239.

https://doi.org/10.1177/146488490100200206

Gershon, Richard A. (2016). Digital media and innovation: Management and design strategies in communication. Los Angeles: Sage Publications. ISBN: 9781452241418

Gholampour-Rad, Masoud (2017). "Disruptive innovation in media industry ecosystem and need for improving managerial cognitive capabilities in polymediation era". Cogent business \& management, v. 4, n. 1, pp. 135-183.

https://doi.org/10.1080/23311975.2017.1352183

Gorin, Valérie (2015). "Innovation (s) in Photojournalism: Assessing visual content and the place of citizen photojournalism in Time's Lightbox photoblog". Digital journalism, v. 3, n. 4, pp. 533-551.

https://doi.org/10.1080/21670811.2015.1034524

Graves, Lucas; Nyhan, Brendan; Reifler, Jason (2016). “Understanding innovations in journalistic practice: A field experiment examining motivations for fact-checking". Journal of communication, v. 66, n. 1.

https://doi.org/102-138. 10.1111/jcom.12198

Graybeal, Geoffrey-Michael; Hayes, Jameson-Lee (2011). “A modified news micropayment model for newspapers on the social web". International journal on media management, v. 13, n. 2, pp. 129-148.

https://doi.org/10.1080/14241277.2011.568808

Groves, Jonathan; Brown, Carrie (2020). Transforming newsrooms: connecting organizational culture, strategy, and innovation. London: Routledge. ISBN: 9781138841277

Grubenmann, Stephanie (2016). "Action research: Collaborative research for the improvement of digital journalism practice". Digital journalism, v. 4, n. 1, pp. 160-176.

https://doi.org/10.1080/21670811.2015.1093274

Günzel, Franziska; Holm, Anna B. (2013). “One size does not fit all - understanding the front-end and back-end of business model innovation". International journal of innovation management, v. 17, n. 1, 1340002.

https://doi.org/10.1142/S1363919613400021

Gynnild, Astrid (2014a). "Journalism innovation leads to innovation journalism: The impact of computational exploration on changing mindsets". Journalism, v. 15, n. 6, pp. 713-730.

https://doi.org/10.1177/1464884913486393

Gynnild, Astrid (2014b). "The robot eye-witness: Extending visual journalism through drone surveillance". Digital journalism, v. 2, n. 3, pp. 334-343.

https://doi.org/10.1080/21670811.2014.883184

Habann, Frank (2008). "Towards a methodological foundation of media innovation research". In: Dal-Zotto, Cinzia; Van-Kranenburg, Hans (eds.). Management and innovation in the media industry. Cheltenham: Edward Elgar Publishing, pp. 67-96. ISBN: 9781847201096

Harlow, Summer (2018). "Quality, innovation, and financial sustainability: Central American entrepreneurial journalism through the lens of its audience". Journalism practice, v. 12, n. 5, pp. 543-564.

https://doi.org/10.1080/17512786.2017.1330663

Harlow, Summer; Chadha, Monica (2018). "Looking for community in community news: An examination of public-spirited content in online local news sites". Journalism, online first.

https://doi.org/10.1177/1464884918805255

Harlow, Summer; Chadha, Monica (2019). “Indian entrepreneurial journalism: Building a typology of how founders' social identity shapes innovation and sustainability". Journalism studies, v. 20, n. 6, pp. 891-910.

https://doi.org/10.1080/1461670X.2018.1463170

Harlow, Summer; Salaverría, Ramón (2016). “Regenerating journalism: Exploring the 'alternativeness' and 'digital-ness' of online-native media in Latin America". Digital journalism, v. 4, n. 8, pp. 1001-1019.

https://doi.org/10.1080/21670811.2015.1135752

Heckman, Meg; Wihbey, John (2019). "The local-mobile paradox: Missed innovation opportunities at local newspapers". Newspaper research journal, v. 40, n. 3, pp. 317-328.

https://doi.org/10.1177/0739532919835610 
Heikka, Taneli; Carayannis, Elias G. (2019). "Three stages of innovation in participatory journalism - co-initiating, co-sensing, and co-creating news in the Chicago School cuts case". Journal of the knowledge economy, v. 10, n. 2, pp. 437-464. https://doi.org/0.1007/s13132-017-0466-0

Hendrickx, Jonathan; Donders, Karen; Picone, Ike (2020). "Innovating journalism by going back in time? The curious case of newsletters as a news source in Belgium". In: Vázquez-Herrero, Jorge; Direito-Rebollal, Sabela; Silva-Rodríguez, Alba; López-García, Xosé (eds.). Journalistic metamorphosis. Media transformation in the digital age. Cham, Springer, pp. 57-68. ISNB: 9783030363147

Hendrickx, Jonathan; Picone, Ike (2020). "Innovation beyond the buzzwords: The rocky road towards a digital first-based newsroom”. Journalism studies, v. 21, n. 14, pp. 2025-2041.

https://doi.org/10.1080/1461670X.2020.1809494

Hepp, Andreas; Loosen, Wiebke (2019). “Pioneer journalism: Conceptualizing the role of pioneer journalists and pioneer communities in the organizational re-figuration of journalism". Journalism, online first.

https://doi.org/10.1177/1464884919829277

Hess, Kristy; Waller, Lisa-Jane (2020a). "Charting the media innovations landscape for regional and rural newspapers". Australian journalism review, v. 42, n. 1, pp. 59-75.

https://doi.org/10.1386/ajr_00019_1

Hess, Kristy; Waller, Lisa-Jane (2020b). "Local newspapers and coronavirus: conceptualising connections, comparisons and cures". Media international Australia, online first.

https://doi.org/10.1177/1329878X20956455

Hewett, Jonathan (2016). "Learning to teach data journalism: Innovation, influence and constraints". Journalism, v. 17, n. 1 , pp. 119-137.

https://doi.org/10.1177/1464884915612681

Holm, Anna B.; Günzel, Franziska; Ulhøi, John P. (2013). “Openness in innovation and business models: Lessons from the newspaper industry". International journal of technology management, v. 61, n. 3-4, pp. 324-348.

https://papers.ssrn.com/sol3/papers.cfm?abstract_id=2243493

Holton, Avery E.; Belair-Gagnon, Valerie (2018). "Strangers to the game: interloper, intraloper and shifting news production". Media and communication, v. 6, n. 4, pp. 70-78.

https://doi.org/10.17645/mac.v6i4.1490

Humphry, Justine; Chesher, Chris (2020). "Preparing for smart voice assistants: Cultural histories and media innovations". New media \& society, online first.

https://doi.org/10.1177/1461444820923679

Imre, Iveta; Wenger, Debora (2020). "Where newsroom leaders see technology facilitating innovation in local TV news". Electronic news, online first.

https://doi.org/10.1177/1931243120963705

Järventie-Thesleff, Rita; Moisander, Johana; Villi, Mikko (2014). "The strategic challenge of continuous change in multi-platform media organizations - A strategy-as-practice perspective". International journal on media management, v. 16, n. 3-4, pp. 123-138.

https://doi.org/10.1080/14241277.2014.919920

Kalogeropoulos, Antonis; Nielsen, Rasmus-Kleis (2018). "Investing in online video news: A cross-national analysis of news organizations' enterprising approach to digital media". Journalism studies, v. 19, n. 15, pp. 2207-2224.

https://doi.org/10.1080/1461670X.2017.1331709

Kaltenbrunner, Andy; Karmasin, Matthias; Kraus, Daniela (eds.) (2017). Journalism-report V: innovation and transition. Vienna: Facultas. ISBN: 9783708915784

Kannengießer, Sigrid (2020). "Fair media technologies: innovative media devices for social change and the good life". The journal of media innovations, v. 6, n. 1, pp. 38-49.

https://doi.org/10.5617/jomi.7832

Khajeheian, Datis; Tadayoni, Reza (2016). "User innovation in public service broadcasts: creating public value by media entrepreneurship". International journal of technology transfer and commercialisation, v. 14, n. 2, pp. 117-131.

https://doi.org/10.1504/IJTTC.2016.081635

Klaß, Nina (2020). "Open innovation in media innovation research - a systematic literature review". Journal of media business studies, v. 17, n. 2, pp. 190-218.

https://doi.org/10.1080/16522354.2020.1724498 
Koivula, Minna; Villi, Mikko; Sivunen, Anu (2020). “Creativity and innovation in technology-mediated journalistic work: mapping out enablers and constraints". Digital journalism, online first.

https://doi.org/10.1080/21670811.2020.1788962

Koliska, Michael; Chadha, Kalyani (2018). "Transparency in German newsrooms: Diffusion of a new journalistic norm?". Journalism studies, v. 19, n. 16, pp. 2400-2416. https://doi.org/10.1080/1461670X.2017.1349549

Konow-Lund, Maria (2020). "Reconstructing investigative journalism at emerging organisations". The journal of media innovations, v. 6, n. 1, pp. 9-22.

https://doi.org/10.5617/jomi.7830

Konow-Lund, Maria; Hågvar, Yngve-Benestad; Olsson, Eva-Karin (2019). "Digital innovation during terror and crises". Digital journalism, v. 7, n. 7, pp. 952-971.

https://doi.org/10.1080/21670811.2018.1493937

Kosterich, Allie (2019). "Managing news nerds: strategizing about institutional change in the news industry". Journal of media business studies, v. 17, n. 1, pp. 51-68.

https://doi.org/10.1080/16522354.2019.1639890

Kosterich, Allie; Weber, Matthew S. (2018). "Starting up the news: The impact of venture capital on the digital news media ecosystem". International journal on media management, v. 20, n. 4, pp. 239-262.

https://doi.org/10.1080/14241277.2018.1563547

Kramp, Leif; Loosen, Wiebke (2018). "The transformation of journalism: From changing newsroom cultures to a new communicative orientation?". In: Andreas Hepp, Andreas Breiter, Uwe Hasebrink (eds.). Transforming communications. London: Palgrave Macmillan, pp. 205-239. ISBN: 9783319655833

Krumsvik, Arne H. (2015). "Newspaper ownership and the prioritization of digital competences". Digital journalism, v. 3, n. 5, pp. 777-790.

https://doi.org/10.1080/21670811.2014.941234

Krumsvik, Arne H.; Milan, Stefania; Bhroin, Niamh-Ni; Storsul, Tanja (2019). "Making (sense of) media innovations". In: Deuze, Mark; Prenger, Mirjam (eds.). Making media: production, practices, and professions. Amsterdam: Amsterdam University Press, pp. 193-206. ISBN: 9789462988118

Küng, Lucy (2008). "Innovation and creativity in the media industry: What? where? how?”. In: Dal-Zotto, Cinzia; Van-Kranenburg, Hans (eds.). Management and innovation in the media industry. Cheltenham: Edward Elgar Publishing, pp. 3-13. ISBN: 9781847201096

Küng, Lucy (2011). "Managing strategy and maximizing innovation in media organizations". In: Deuze, Mark (ed.). Managing media work. Los Angeles: Sage, pp. 43-56. ISBN: 9781412971249

Küng, Lucy (2013). "Innovation, technology and organisational change. Legacy media's big challenges. An introduction". In: Storsul, Tanja; Krumsvik, Arne (eds.). Media innovations. A multidisciplinary study of change. Göteborg: Nordicom, pp. 9-12. ISBN: 9789186523657

Küng, Lucy (2015). Innovators in digital news. London: Reuters Institute for the Study of Journalism; I. B. Tauris. ISBN: 9781784534165

Lajqi, Margarita; Lischka, Juliane A. (2020). "Normative principles in newsroom innovation. The case of $360^{\circ}$ video adoption by editorial knowledge champions". The journal of media innovations, online first.

https://doi.org/10.1177/1464884913511565

Lamot, Kenza; Paulussen, Steve (2020). "Six uses of analytics: Digital editors' perceptions of audience analytics in the newsroom". Journalism practice, v. 14, n. 3, pp. 358-373.

https://doi.org/10.1080/17512786.2019.1617043

Leenders, Mark A. A. M.; Farrell, Mark A.; Van-der-Wurff, Richard (2016). "Market or society? Dual orientations and the impact on innovativeness in media organizations". Journal of strategic marketing, v. 25, n. 5-6, pp. 439-453. https://doi.org/10.1080/0965254X.2016.1149209

Lehtisaari, Katja-Ulhøi; Villi, Mikko; Grönlund, Mikko; Lindén, Carl-Gustav; Mierzejewska, Bozena I.; Picard, Robert; Roepnack, Axel (2018). "Comparing innovation and social media strategies in Scandinavian and US newspapers". Digital journalism, v. 6, n. 8, pp. 1029-1040.

https://doi.org/10.1080/21670811.2018.1503061

Lewis, Seth C. (2011). "Journalism innovation and participation: An analysis of the Knight News Challenge”. International journal of communication, v. 5, pp. 1623-1648.

https://ijoc.org/index.php/ijoc/article/view/1140 
Lewis, Seth C. (2012). "From journalism to information: The transformation of the Knight Foundation and news innovation". Mass communication and society, v. 15, n. 3, pp. 309-334.

https://doi.org/10.1080/15205436.2011.611607

Lewis, Seth C.; Usher, Nikki (2013). “Open source and journalism: Toward new frameworks for imagining news innovation". Media, culture \& society, v. 35, n. 5, pp. 602-619.

https://doi.org/10.1177/0163443713485494

Lewis, Seth C.; Usher, Nikki (2014). "Code, collaboration, and the future of journalism: A case study of the hacks/hackers global network". Digital journalism, v. 2, n. 3, pp. 383-393.

https://doi.org/10.1080/21670811.2014.895504

Lewis, Seth C.; Usher, Nikki (2016). "Trading zones, boundary objects, and the pursuit of news innovation: A case study of journalists and programmers". Convergence: the international journal of research into new media technologies, v. 22 , n. 5, pp. 543-560.

https://doi.org/10.1177/1354856515623865

Lewis, Seth C.; Westlund, Oscar (2015). "Big data and journalism: Epistemology, expertise, economics, and ethics". Digital journalism, v. 3, n. 3, pp. 447-466.

https://doi.org/10.1080/21670811.2014.895504

Lievrouw, Leah A. (2006) "New media design and development: Diffusion of innovations v. social shaping of technology". In: Lievrouw, Leah A.; Livingstone, Sonia (eds.). Handbook of new media: Social shaping and consequences of ICTS, $2^{\text {nd }}$ ed. London: Sage, pp. 246-265.

https://doi.org/10.4135/9781446211304

Lindén, Carl-Gustav (2015). "Media innovation in a strange place: Newspaper differentiation on Åland". The journal of media innovations, v. 2, n. 2, pp. 40-57.

https://doi.org/10.5617/jmi.v2i2.993

Lindén, Carl-Gustav (2017). "Algorithms for journalism: The future of news work". The journal of media innovations, v. 4, n. 1, pp 60-76.

https://doi.org/10.5617/jmi.v4i1.2420

Lindmark, Sven; Ranaivoson, Heritiana; Donders, Karen; Ballon, Pieter (2013). "Innovation in small regions' media sectors. Assessing the impact of policy in Flanders". In: Storsul, Tanja; Krumsvik, Arne H. (eds.). Media innovations. A multidisciplinary study of change. Göteborg: Nordicom, pp. 127-144. ISBN: 9789186523657

Lischka, Juliane A. (2015). "How structural multi-platform newsroom features and innovative values alter journalistic cross-channel and cross-sectional working procedures". Journal of media business studies, v. 12, n. 1, pp. 7-28.

https://doi.org/10.1080/16522354.2015.1027114

López-García, Xosé; Silva-Rodríguez, Alba; Negreira-Rey, María C. (2019). “Laboratory journalism”. In: Túñez-López, Miguel; Martínez-Fernández, Valentín-Alejandro; López-García, Xosé; Rúas-Araújo, Xosé; Campos-Freire, Francisco (eds.). Communication: Innovation \& quality. Cham, Springer, pp. 147-162. ISBN: 9783319918600

López-Golán, Mónica; Rodríguez-Castro, Marta; Campos-Freire, Francisco (2019). "La innovación de las radiotelevisiones públicas europeas en la comunicación digital y las comunidades de usuarios". Cuadernos.info, n. 45, pp. 241-255. https://doi.org/10.7764/cdi.45.1350

López-Hidalgo, Antonio; Ufarte-Ruiz, María-José (2016). “Laboratorios de periodismo en España. Nuevas narrativas y retos de futuro". Ámbitos, n. 34, pp. 1-12.

https://revistascientificas.us.es/index.php/Ambitos/article/view/9360

Lowe, Gregory-Ferrell; Stavitsky, Alan G. (2016). "Ensuring public service news provision in the era of networked communications". International communication gazette, v. 78, n. 4, pp. 311-329.

https://doi.org/10.1177/1748048516632163

Lowrey, Wilson (2011). “Institutionalism, news organizations and innovation”. Journalism studies, v. 12, n. 1, pp. 64-79. https://doi.org/10.1080/1461670X.2010.511954

Lowrey, Wilson (2012). "Journalism innovation and the ecology of news production: Institutional tendencies". Journalism \& communication monographs, v. 14, n. 4, pp. 214-287.

https://doi.org/10.1177/1522637912463207

Lowrey, Wilson; Sherrill, Lindsey; Broussard, Ryan (2019). “Field and ecology approaches to journalism innovation: The role of ancillary organizations". Journalism studies, v. 20, n. 15, pp. 2131-2149.

https://doi.org/10.1080/1461670X.2019.1568904 
Lund, Anker B. (2008). "Diffusion of innovation in news organizations: Action research of middle managers in Danish mass media”. In: Dal-Zotto, Cinzia; Van-Kranenburg, Hans (eds.). (2008). Management and innovation in the media industry. Cheltenham: Edward Elgar Publishing, pp. 199-214. ISBN: 9781847201096

Mabrook, Radwa; Singer, Jane B. (2019). "Virtual reality, 360 video, and journalism studies: conceptual approaches to immersive technologies". Journalism studies, v. 20, n. 14, pp. 2096-2112.

https://doi.org/10.1080/1461670X.2019.1568203

Malmelin, Nando; Virta, Sari (2016). “Managing creativity in change: Motivations and constraints of creative work in a media organisation". Journalism practice, v. 1, n. 8, pp. 1041-1054.

https://doi.org/10.1080/17512786.2015.1074864

Mancebo-García, Marina (2016). “Innovación en formatos audiovisuales. El uso de herramientas de live streaming en Antena 3 y Univision”. Miguel Hernández communication journal, n. 7, pp. 325-349.

https://dialnet.unirioja.es/descarga/articulo/5794585.pdf

Manfredi-Sánchez, Juan-Luis (coord.) (2015). Innovación y periodismo. Emprender en la universidad. Tenerife: Cuadernos artesanos de comunicación, n. 76. http://www.revistalatinacs.org/067/cuadernos/2015/cac76.pdf

Manfredi-Sánchez, Juan-Luis; Rojas-Torrijos, José-Luis; Herranz-de-la-Casa, José-María (2015). "Innovación en el periodismo emprendedor deportivo: modelo de negocio y narrativas". El profesional de la información, v. 24, n. 3, pp. 265-273.

https://doi.org/10.3145/epi.2015.may.06

Manfredi-Sánchez, Juan-Luis; Ufarte-Ruiz, María-José; Herranz-de-la-Casa, José-María (2019). “Journalistic innovation and digital society: An adaptation of journalism studies". Revista latina de comunicación social, n. 74, pp. 1633 -1654. https://doi.org/10.4185/RLCS-2019-1402

Martínez-Fernández, Valentín-Alejandro; Juanatey-Boga, Óscar; Crespo-Pereira, Verónica (2018). "Acciones de innovación de las radiotelevisiones públicas europeas". In: Pérez-Seijo, Sara; Rodríguez-Castro, Marta; Túñez-López, Miguel (eds.). Debates sobre valores e indicadores del servicio audiovisual público en Europa. Cuadernos Artesanos de Comunicación. La Laguna: Latina, pp. 17-31.

http://www.cuadernosartesanos.org/2018/cac142.pdf

McKelvie, Alexander; Wiklund, Johan (2008). "Understanding innovation in new and young media firms". In: Dal-Zotto, Cinzia; Van-Kranenburg, Hans (eds.). Management and innovation in the media industry. Cheltenham: Edward Elgar Publishing, pp. 15-35. ISBN: 9781847201096

Meier, Klaus (2007). "Innovations in Central European newsrooms: Overview and case study". Journalism practice, v. 1, n. 1, pp. 4-19. https://doi.org/10.1080/17512780601078803

Meier, Klaus; Bracker, Isabel; Verhovnik, Melanie (2017). “Technological innovation and convergent journalism: case study on the transformation process of Bavaria's public broadcasting service". Revista mediterránea de comunicación, v. 8, n. 1, pp. 33-44.

https://doi.org/10.14198/MEDCOM2017.8.1

Mendiguren-Galdospin, Teresa; Agirreazkuenaga-Onaindia, Irati; Meso-Ayerdi, Koldo (2019). "Digital news start-ups in Spain: symbolic and social capital as drivers of success". Estudios sobre el mensaje periodístico, v. 25, n. 1, pp. 393-409. https://doi.org/10.5209/ESMP.63736

Menduni, Enrico (2007). "Four steps in innovative radio broadcasting: From QuickTime to podcasting". The radio journal - international studies in broadcast and audio media, v. 5, n. 1, pp. 9-18.

https://doi.org/10.1386/rajo.5.1.9_1

Meneses-Fernández, María-Dolores; Martín-Gutiérrez, Jorge (2013). "Realidad aumentada e innovación tecnológica en prensa. La experiencia de ver y escuchar un periódico impreso". Estudios sobre el mensaje periodístico, v. 19, n. 1, pp. 207-222.

https://doi.org/10.5209/rev_ESMP.2013.v19.n1.42517

Micó, Josep-Lluís, Masip, Pere; Domingo, David (2013). "To wish impossible things*: Convergence as a process of diffusion of innovations in an actor-network". International communication gazette, v. 75, n. 1, pp. 118-137. https://doi.org/10.1177/1748048512461765

Mierzejewska, Bozena I. (2011). "Media management in theory and practice". In: Deuze, Mark (ed.). Managing media work. Thousand Oaks: Sage Publications, pp. 13-30. ISBN: 9781412971249 
Mills, John; Pellanda, Eduardo; Pase, André (2017). “New interactions: The relationship between journalists and audiences mediated by Google Glass". Journalism practice, v. 11, n. 8, pp. 980-999.

https://doi.org/10.1080/17512786.2016.1224679

Mitchelstein, Maria-Elena; Boczkowski, Pablo J. (2009). "Between tradition and change: A review of recent research on online news production". Journalism, v. 10, n. 5, pp. 562-586.

https://doi.org/10.1177/1464884909106533

Mitchelstein, Maria-Elena; Boczkowski, Pablo J.; Wagner, Maria-Celeste (2017). "The boomerang effect: innovation in the blogs of mainstream news sites, 2008-2012". Media, culture \& society, v. 39, n. 8, pp. 1231-1244.

https://doi.org/10.1177/0163443717690819

Moreira-Flores, Ana M. (2017). “Innovation journalism: a multiple concept”. Brazilian journalism research, v. 13, n. 2, pp. $156-179$. https://bjr.sbpjor.org.br/bjr/article/view/970

Mütterlein, Joschka; Kunz, Reinhard E. (2017). “Innovate alone or with others? Influence of entrepreneurial orientation and alliance orientation on media business model innovation". Journal of media business studies, v. 14, n. 3, pp. $173-187$. https://doi.org/10.1080/16522354.2018.1445162

Nee, Rebecca C. (2013). "Creative destruction: An exploratory study of how digitally native news nonprofits are innovating online journalism practices". International journal on media management, v. 15, n. 1, pp. 3-22.

https://doi.org/10.1080/14241277.2012.732153

Nel, François P. (2010). "Where else is the money? A study of innovation in online business models at newspapers in Britain's 66 cities". Journalism practice, v. 4, n. 3, pp. 360-372.

https://doi.org/10.1080/17512781003642964

Nel, François P.; Milburn-Curtis, Coral; Lehtisaari, Katja (2020). Successful exploration: Organisational ambidexterity and performance in news media firms. Nordic journal of media management, v. 1, n. 1, pp. 45-62.

https://doi.org/10.5278/njmm.2597-0445.3495

Nguyen, An (2008). “Facing 'the fabulous monster'. The traditional media's fear-driven innovation culture in the development of online news". Journalism studies, v. 9, n. 1, pp. 91-104.

https://doi.org/10.1080/14616700701768147

Nicey, Jérémie (2013). "Between reactivity and reactivation. User-generated news photo agencies, new practices, and traditional processes". In: Storsul, Tanja; Krumsvik, Aarne H. (eds.). Media innovations. A multidisciplinary study of change. Göteborg: Nordicom, pp. 207-218. ISBN: 9789186523657

Nielsen, Rasmus K. (2012). "How newspapers began to blog: Recognizing the role of technologists in old media organizations' development of new media technologies". Information, communication \& society, n. 15, p. 6, pp. 959-978. https://doi.org/10.1080/1369118X.2012.694898

Nunes, Ana-Cecilia B.; Canavilhas, João (2020). "Journalism innovation and its influences in the future of news: a European perspective around Google DNI Fund initiatives". In: Vázquez-Herrero, Jorge; Direito-Rebollal, Sabela; Silva-Rodríguez, Alba; López-García, Xosé (eds.). Journalistic metamorphosis. Media transformation in the digital age. Springer, Cham, pp. 41-56. ISBN: 9783030363147

Oelrichs, Inga (2020). "Adoption of innovations in digital sports journalism: The use of Twitter by German sports journalists". Communication \& sport, online first.

https://doi.org/10.1177/2167479520961786

Ostertag, Stephen F.; Tuchman, Gaye (2012). "When innovation meets legacy. Citizen journalists, ink reporters and television news". Information, communication \& society, v. 15, n. 6, pp. 909-931.

https://doi.org/10.1080/1369118X.2012.676057

Owens, John W.; Dillman-Carpentier, Francesca (2004). "Radio station innovation and risk taking: A survey of programmers and general managers". International journal on media management, v. 6, n. 3-4, pp. 226-234.

https://doi.org/10.1080/14241277.2004.9669405

Palacios, Marcos; Barbosa, Suzana; Da-Silva, Fernando-Firmino; Da-Cunha, Rodrigo (2016). “Mobile journalism and innovation: A study on content formats of autochthonous news apps for tablets". In: Aguado, Juan-Miguel; Feijóo, Carlos; Martínez, Inmaculada (eds.). Emerging perspectives on the mobile content evolution. Hershei: IGI Global, pp. $239-262$. https://doi.org/10.4018/978-1-4666-8838-4.ch013

Palomo, Bella; Palau-Sampio, Dolors (2016). “El periodista adaptativo. Consultores y directores de innovación analizan las cualidades del profesional de la comunicación”. El profesional de la información, v. 25, n. 2, pp. 188-195.

https://doi.org/10.3145/epi.2016.mar.05 
Parra-Valcarce, David; Martínez-Arias, Santiago M. (2019). “Creación de docuwebs: gestión de nuevos géneros periodísticos online". El profesional de la información, v. 28, n. 4, e280420. https://doi.org/10.3145/epi.2019.jul.20

Paterson, Chris (ed.). (2019). Journalism and social media in Africa: studies in innovation and transformation. London: Routledge. ISBN: 9780415745260

Paucar-Carrión, Katty; Coronel-Salas, Gabriela (2019). "Laboratorios: un recurso para la innovación periodística”. Revista ibérica de sistemas e tecnologias de informação, n. E20, pp. 477-489.

https://search.proquest.com/openview/6f599e35910da632495362b772d95470/1

Paulussen, Steve (2016). "Innovation in the newsroom”. In: Witschge, Tamara; Anderson, C. W.; Domingo, David; Hermida, Alfred (eds.). The Sage handbook of digital journalism. London: Sage, pp. 192-206. ISBN: 9781473906532

Paulussen, Steve; Geens, Davy; Vandenbrande, Kristel (2011). "Fostering a culture of collaboration: organizational challenges of newsroom innovation". In: Domingo, David; Paterson, Chris (eds.). Making online news. Newsroom ethnographies in the second decade of internet journalism. New York: Peter Lang, v. 2, pp. 3-14. ISBN: 9781433110641

Pavlik, John V. (2013). "A vision for transformative leadership: Rethinking journalism and mass communication education for the twenty-first century". Journalism \& mass communication educator, v. 68, n. 3, pp. 211-221.

https://doi.org/10.1177/1077695813499561

Pavlik, John V. (2013). "Innovation and the future of journalism”. Digital journalism, v. 1, n. 2, pp. 181-193. https://doi.org/10.1080/21670811.2012.756666

Peña-Fernández, Simón; Lazkano-Arrillaga, Iñaki; Larrondo-Ureta, Ainara (2019). “Medios de comunicación e innovación social. El auge de las audiencias activas en el entorno digital”. Andamios, v. 16, n. 40.

https://doi.org/10.29092/uacm.v16i40.710

Peñafiel-Sáiz, Carmen (2016). "Reinvención del periodismo en el ecosistema digital y narrativas transmedia", adComunica, n. 12, pp. 163-182.

http://hdl.handle.net/10234/167719

Pérez-Seijo, Sara; Benítez-de-Gracia, María-José (2018). "Las narrativas inmersivas como valor de innovación en las radiotelevisiones públicas europeas". In: Pérez-Seijo, Sara, Rodríguez-Castro, Manuel; Túñez-López, Miguel (eds.). Debates sobre valores e indicadores del servicio audiovisual público en Europa. Cuadernos Artesanos de Comunicación. La Laguna (Tenerife): Latina, pp. 111-126.

http://www.cuadernosartesanos.org/2018/cac142.pdf

Pettersen, Lene; Krumsvik, Arne H. (2019). "Rocking the boat: Proposing a participatory business model for news". The journal of media innovations, online first.

https://doi.org/10.5617/jomi.6561

Picard, Robert G. (2000). "Audience fragmentation and structural limits on media innovation and diversity". In: Van-Cuilenburg, Jan; Van-der-Wurff, Richard (eds.). Media and open societies: cultural, economic and policy foundations for media openness and diversity in East and West, pp. 180-191. Amsterdam: Spinhuis. ISBN: 9789055891795

Plesner, Ursula (2009). "An actor-network perspective on changing work practices: communication technologies as actants in news work". Journalism, v. 10, n. 5, pp. 604-626.

https://doi.org/10.1177/1464884909106535

Plewe, Christoph; Fürsich, Elfriede (2020). "Producing newsgames beyond boundaries: Journalists, game developers, and the news business". Convergence: the international journal of research into new media technologies, online first. https://doi.org/10.1177/1354856520918076

Porcu, Ornella (2017). "Exploring innovative learning culture in the newsroom”. Journalism, v. 21, n. 10, pp. 1556-1572. https://doi.org/10.1177/1464884917724596

Porcu, Ornella; Hermans, Liesbeth; Broersma, Marcel (2020). “Unlocking the newsroom: measuring journalists' perceptions of innovative learning culture". Journalism studies, v. 21, n. 10, pp. 1420-1438.

https://doi.org/10.1080/1461670X.2020.1758956

Powers, Matthew (2012). "'In forms that are familiar and yet-to-be invented': American journalism and the discourse of technologically specific work". Journal of communication inquiry, v. 36, n. 1, pp. 24-43.

https://doi.org/10.1177/0196859911426009

Powers, Matthew; Vera-Zambrano, Sandra (2016). "Explaining the formation of online news startups in France and the United States: A field analysis". Journal of communication, v. 66, n. 5, pp. 857-877.

https://doi.org/10.1111/jcom.12253 
Pozo-Montes, Yaiza; Larrondo-Ureta, Ainara (2020). “Revisión de los factores de innovación en periodismo: análisis de laboratorios de medios". ZER, v. 25, n. 48, pp. 191-210.

https://doi.org/10.1387/zer.21417

Prenger, Mirjam; Deuze, Mark (2017). "A history of innovation and entrepreneurialism in journalism”. In: Boczkowski, Pablo J.; Anderson, C. W. (eds.). Remaking the news. Essays on the future of journalism scholarship in the digital age, pp. 235-250. Cambridge, Massachusetts: MIT Press. ISBN: 9780262036092

Prudkin, Gonzalo; Mielniczuk, Luciana P. (2019). “El periodismo dron: ¿innovación, disrupción o continuidad? Un estudio teórico retrospectivo sobre la captación de imágenes aéreas en el contexto de una cultura visual". Contemporânea, v. 17, n. 1, pp. 70-98.

https://doi.org/10.9771/contemporanea.v17i1.26943

Puijk, Roel (2015). "Slow television: a successful innovation in public service broadcasting". Nordicom review, v. 36, n. 1, pp. 95-108.

https://doi.org/10.1515/nor-2015-0008

Raetzsch, Christoph (2015). “Innovation through practice: Journalism as a structure of public communication”. Journalism practice, v. 9, n. 1, pp. 65-77.

https://doi.org/10.1080/17512786.2014.928466

Ranaivoson, Heritiana; Farchy, Joëlle; Gansemer, Mathilde (2013). “Differentiated strategies for digital innovation on television: Traditional channels vs. new entrants". Observatorio (OBS*), v. 7, n. 4, pp. 23-44.

http://obs.obercom.pt/index.php/obs/article/view/659/638

Ritter-Longhi, Rita; Flores, Ana-Marta (2017). "Webjournalist narratives as an element of innovation: cases of Al Jazeera, Folha de S. Paulo, The Guardian, The New York Times and The Washington Post". Intercom: Revista brasileira de ciências da comunicação, v. 40, n. 1, pp. 21-40.

https://doi.org/10.1590/1809-5844201712

Røe-Mathisen, Birgit; Morlandstø, Lisbeth (2018). "Innovating contextual genres. A strategy to sustain regional democratic relevance?". Sur le journalisme, v. 7, n. 2.

http://www.surlejournalisme.com/rev

Rogers, Everett M. (2003). Diffusion of innovations (5 $5^{\text {th }}$ ed.). New York: Free Press. ISBN: 9780743222099

Rojas-Torrijos, José-Luis (2013). “Periodismo deportivo. Hacia la innovación y el emprendimiento en la red”. In: Sobrados-León, Maritza (coord.). Presente y futuro en el periodismo especializado, pp. 197-247. Madrid: Fragua. ISBN: 97884 70745553

Rojas-Torrijos, José-Luis (2014). "Sports journalism, dissemination and innovation. A case study of the international news coverage of the 2014 Winter Olympic Games". Textual \& visual media: revista de la sociedad española de periodística, n. 7, pp. 117-130.

Rojas-Torrijos, José-Luis; González-Alba, José-Antonio (2018). “La newsletter como producto periodístico en la búsqueda de nuevos lectores. Estudio de boletines de noticias de El País, El Español y El Independiente”. adComunica, n. 15, pp. 165-195.

https://www.e-revistes.uji.es/index.php/adcomunica/article/view/4972

Rojas-Torrijos, José-Luis; Panal-Prior, Antonio (2017). “El uso de Instagram en los medios de comunicación deportivos. Análisis comparado de Bleacher Report, L'équipe y Marca”. Ámbitos: revista internacional de comunicación, n. 38, pp. 1-19.

https://revistascientificas.us.es/index.php/Ambitos/article/view/9097

Ryfe, David M. (2009a). "Broader and deeper: A study of newsroom culture in a time of change". Journalism, v. 10, n. 2, pp. 197-216.

https://doi.org/10.1177/1464884908100601

Ryfe, David M. (2009b). "Structure, agency, and change in an American newsroom”. Journalism, v. 10, n. 5, pp. 665-683. https://doi.org/10.1177/1464884909106538

Sádaba-Chalezquer, Charo; Salaverría, Ramón (2016). “La innovación y los cibermedios: los labs”. In: Sádaba-Chalezquer, Charo; García-Avilés, José-Alberto; Martínez-Costa, María-Pilar (coords.). Innovación y desarrollo de los cibermedios en España, pp. 41-47. Eunsa: Pamplona. ISBN: 9788431331252

Sádaba-Chalezquer, Charo; García-Avilés, José-Alberto; Martínez-Costa, María-Pilar (2016). Innovación y desarrollo de los cibermedios en España. Eunsa: Pamplona. ISBN: 9788431331252 
Salaverría, Ramón (2015). "Los 'labs' como fórmula de innovación en los medios”. El profesional de la información, v. 24, n. 4, pp. 397-404.

https://doi.org/10.3145/epi.2015.jul.06

Salaverría, Ramón; Sádaba-Chalezquer, Charo; Breiner, James; Warner, Janine C. (2019). "A brave new digital journalism in Latin America". In: Túñez-López, Miguel; Martínez-Fernández Valentín-Alejandro; López-García, Xosé; Rúas-Araújo, Xosé; Campos-Freire, Francisco (eds.). Communication: innovation \& quality, pp. 229-247. Cham, Springer. ISBN: 978 3319918600

Sánchez-Gonzales, Hada M.; Sánchez-González, María (2017). "Los bots como servicio de noticias y de conectividad emocional con las audiencias. El caso de Politibot". Doxa comunicación, n. 25, pp. 63-84.

https://recyt.fecyt.es/index.php/doxacom/article/view/61946

Sánchez-Gonzales, Hada M.; Sánchez-González, María (2020). "Conversational bots used in political news from the point of view of the user's experience: Politibot". Communication \& society, v. 33, n. 4, pp. 155-168.

https://doi.org/10.15581/003.33.4.155-168

Santín, Marina; Álvarez-Monzoncillo, José-María (2020). "The use of YouTube by the Spanish press: A model to be defined". El profesional de la información, v. 29, n. 1, e290116.

https://doi.org/10.3145/epi.2020.ene.16

Santos-Silva, Dora (2020). "Paradigmatic innovation in European cultural journalism: the pursuit of sustainability". The journal of media innovations, online first.

https://doi.org/10.5617/jomi.6523

Schmitz-Weiss, Amy; De-Macedo-Higgins-Joyce, Vanessa; Harlow, Summer; Calmon-Alves, Rosental (2018). “Innovation and sustainability: a relationship examined among Latin American entrepreneurial news organizations". Cuadernos. info, n. 42, pp. 87-100.

https://doi.org/10.7764/cdi.42.1266

Schmitz-Weiss, Amy; De-Macedo-Higgins-Joyce, Vanessa; Harlow, Summer; Calmon-Alves, Rosental (2020). “Defining journalism innovation in Latin America: exploration into perceptions among educators, students, and journalists". Journalism \& mass communication educator, v. 75, n. 4, pp. 419-435.

https://doi.org/10.1177/1077695820935327

Schmitz-Weiss, Amy; Domingo, David (2010). "Innovation processes in online newsrooms as actor-networks and communities of practice". New media \& society, v. 12, n. 7, pp. 1156-1171.

https://doi.org/10.1177/1461444809360400

Schmitz-Weiss, Amy; Wulfemeyer, Tom (2014). "Newspapers, TV news offer more online innovation". Newspaper research journal, v. 35, n. 2, pp. 100-118.

https://doi.org/10.1177/073953291403500208

Schoder, Detlef; Sick, Stefan; Putzke, Johanes; Kaplan, Andreas M. (2006). "Mass customization in the newspaper industry: Consumers' attitudes toward individualized media innovations". International journal on media management, $\mathrm{v}$. 8, n. 1, pp. 9-18.

https://doi.org/10.1207/s14241250ijmm0801_3

Schweizer, T. Sophie (2003). "Managing interactions between technological and stylistic innovation in the media industries". Technology analysis \& strategic management, v. 15, n. 1, pp. 19-41.

https://doi.org/10.1080/0953732032000046033

Sekloča, Peter (2015). "Contradictions of media production and the heterogeneity of products". Javnost-the public, v. 22, n. 2, pp. 129-144.

https://doi.org/10.1080/13183222.2015.1045713

Siapera, Eugenia; Papadopoulou, Lambrini (2016). "Entrepreneurialism or cooperativism? An exploration of cooperative journalistic enterprises". Journalism practice, v. 10, n. 2, pp. 178-195.

https://doi.org/10.1080/17512786.2015.1125760

Singer, Jane B. (2004). "Strange bedfellows? The diffusion of convergence in four news organizations". Journalism studies, v. 5, n. 1, pp. 3-18.

https://doi.org/10.1080/1461670032000174701

Singer, Jane B. (2014). "Getting past the future: journalism ethics, innovation, and a call for 'flexible first'”. Comunicação e sociedade, v. 25, pp. 67-82.

https://doi.org/10.17231/comsoc.25(2014).1860 
Singer, Jane B.; Broersma, Marcel (2020). “Innovation and entrepreneurship: Journalism students' interpretive repertoires for a changing occupation". Journalism practice, v. 14, n. 3, pp. 319-338.

https://doi.org/10.1080/17512786.2019.1602478

Sjøvaag, Helle; Krumsvik, Arne H. (2018). "In search of journalism funding: scenarios for future media policy in Norway". Journalism practice, v. 12, n. 9, pp. 1201-1219.

https://doi.org/10.1080/17512786.2017.1370972

Slaček-Brlek, Sašo; Smrke, Jurij; Vobič, Igor (2017). “Engineering technologies for journalism in the digital age: A case study". Digital journalism, v. 5, n. 8, pp. 1025-1043.

https://doi.org/10.1080/21670811.2017.1338526

Slot, Mijke (2018). "About introvert incumbents and extravert start-ups: An exploration of the dialectics of collaborative innovation in the Dutch journalism field". Journalism, online first.

https://doi.org/10.1177/1464884918794303

Socolow, Michael J. (2010). "A profitable public sphere: the creation of The New York Times Op-ed page". Journalism \& mass communication quarterly, v. 87, n. 2, pp. 281-296.

https://doi.org/10.1177/107769901008700204

Sommer, Cristoph (2018). "Market orientation of news startups". The journal of media innovations, v. 4, n. 2, pp. 35-54. https://doi.org/10.5617/jomi.v4i2.1507

Spyridou, Lia-Paschalia; Matsiola, Maria; Veglis, Andreas; Kalliris, George; Dimoulas, Charalambos (2013). "Journalism in a state of flux: Journalists as agents of technology innovation and emerging news practices". International communication gazette, v. 75, n. 1, pp. 76-98.

https://doi.org/10.1177/1748048512461763

Steensen, Steen (2009). "What's stopping them? Towards a grounded theory of innovation in online journalism". Journalism studies, v. 10, n. 6, pp. 821-836.

https://doi.org/10.1080/14616700902975087

Steensen, Steen (2011). "Online journalism and the promises of new technology". Journalism studies, v. 12, n. 3, pp. 311-327.

https://doi.org/10.1080/1461670X.2010.501151

Steensen, Steen (2013). "Balancing the bias. The need for counter-discursive perspectives in media innovation research". In: Storsul, Tanja; Krumsvik, Arne H. (eds.). Media innovations. A multidisciplinary study of change. Göteborg: Nordicom, pp. 45-60. ISBN: 97891086523657

Stonbely, Sarah; Weber, Matthew S.; Satullo, Christopher (2020). "Innovation in public funding for local journalism: A case study of New Jersey's 2018 Civic Information Bill”. Digital journalism, v. 8, n. 6, pp. 740-757.

https://doi.org/10.1080/21670811.2020.1749102

Storsul, Tanja; Krumsvik, Arne H. (2013). "What is media innovation?”. In: Storsul, Tanja; Krumsvik, Arne H. (eds.). Media innovation: A multidisciplinary study of change. Gothenburg: Nordicom, pp. 13-26. ISBN: 9789186523657

Sylvie, George (2017). "Creating innovative news: The values of future newsroom managers". In: Altmeppen, Klaus-Dieter; Hollifield, C. Ann; Van-Loon, Joost (eds.). Value-oriented media management: decision making between profit and responsibility. Cham, Springer, pp. 95-108. ISBN 9783319510088

Sylvie, George; Schmitz-Weiss, Amy (2012). "Putting the management into innovation \& media management studies: A meta-analysis". International journal on media management, v. 14, n. 3, pp. 183-206.

https://doi.org/10.1080/14241277.2011.633584

Toural-Bran, Carlos; Vizoso, Ángel; Pérez-Seijo, Sara; Rodríguez-Castro, Marta; Negreira-Rey, María-Cruz (eds.) (2020). Information visualization in the era of innovative journalism. London: Routledge. ISBN: 9780367408763

Trappel, Joseph (2015). "What to study when studying media and communication innovation? Research design for the digital age". The journal of media innovations, v. 2, n. 1, pp. 7-22.

https://doi.org/10.5617/jmi.v2i1.879

Trillo-Domínguez, Magdalena; Alberich-Pascual, Jordi (2020). "Análisis y tipificación de formatos emergentes en el ciberperiodismo español: de la adaptación multimedia a la disrupción transmedia”. Estudios sobre el mensaje periodístico, v. 26 , n. 1, pp. 652-668.

https://doi.org/10.5209/esmp.67317

Túñez-López, Miguel; Martínez-Fernández, Valentín-Alejandro; López-García, Xosé; Rúas-Araújo, Xosé; Campos-Freire, Francisco (eds.) (2019). Communication: Innovation \& quality. studies in systems, decision, and control. Springer, Cham. ISBN: 9783319918600 
Usher, Nikki (2017). "Venture-backed news startups and the field of journalism”. Digital journalism, v. 5, n. 9, pp. 1116-1133. https://doi.org/10.1080/21670811.2016.1272064

Valanto, Vera; Kosonen, Miia; Ellonen, Hanna-Kaisa (2012). “Are publishers ready for tomorrow? publishers' capabilities and online innovations". International journal of innovation management, v. 16, n. 1, pp. 1-18.

https://doi.org/10.1142/S1363919611003362

Valarezo-Cambizaca, Luis-Mario; Rodríguez-Hidalgo, Claudia (2019). "La innovación en el periodismo como antídoto ante las fake news". Revista ibérica de sistemas e tecnologias de informação, n. E20, pp. 24-35.

https://search.proquest.com/openview/5a6e4c02ea3ee75912f13fc87c888fc5/1.pdf

Valero-Pastor, José-María (2015). “Tendencias de la innovación mediática en Estados Unidos”. Miguel Hernández communication journal, n. 6, pp. 161-193.

https://doi.org/10.21134/mhcj.v0i6.84

Valero-Pastor, José-María; Carvajal-Prieto, Miguel (2019). “Knowledge transfer for the social era within journalistic organisations. A study of Spanish cases". Revista latina de comunicación social, n. 74, pp. 1154-1172.

https://doi.org10.4185/RLCS-2019-1376en

Valero-Pastor, José-María; Carvajal-Prieto, Miguel; García-Avilés, José-Alberto (2019). “Flujos de trabajo para el periodismo postindustrial: métodos y programas para una comunicación organizacional más ágil y transversal". El profesional de la información, v. 28, n. 5, e280514.

https://doi.org/10.3145/epi.2019.sep.14

Valero-Pastor, José-María; González-Alba, José-Antonio (2018). “Las startups periodísticas como ejemplos de innovación en el mercado mediático español. Estudio de casos”. Revista latina de comunicación social, n. 73, pp. 556-582. https://doi.org/10.4185/RLCS-2018-1269

Vállez, Mari; Codina, Lluís (2018). "Periodismo computacional: evolución, casos y herramientas". El profesional de la información, v. 27, n. 4, pp. 759-768.

https://doi.org/10.3145/epi.2018.jul.05

Van-Dalen, Arjen (2012). "The algorithms behind the headlines: How machine-written news redefines the core skills of human journalists". Journalism practice, v. 6, n. 5-6, pp. 648-658.

https://doi.org/10.1080/17512786.2012.667268

Van-der-Wurff, Richard; Leenders, Mark (2008). “Media organizational culture and innovative performance”. In: Dal-Zotto, Cinzia; Van-Kranenburg, Hans (eds.). Management and innovation in the media industry. Cheltenham: Edward Elgar Publishing, pp. 151-171. ISBN: 9781847201096

Van-Kerkhoven, Marco; Bakker, Piet (2014). "The hyperlocal in practice: Innovation, creativity and diversity". Digital journalism, v. 2, n. 3, pp. 296-309.

https://doi.org/10.1080/21670811.2014.900236

Van-Kranenburg, Hands (ed.) (2017). Innovation policies in the European news media industry. Cham, Springer International. ISBN: 9783319452043

Van-Weezel, Aldo (2010). “Creative destruction: Why not researching entrepreneurial media?" International journal on media management, v. 12, n. 1, pp. 47-49.

https://doi.org/10.1080/14241270903558442

Vara-Miguel, Alfonso (2016). “El Confidencial: innovar en contenido como clave del éxito”. In: Sádaba-Chalezquer, Charo; García-Avilés, José-Alberto; Martínez-Costa, María-Pilar (2016). Innovación y desarrollo de los cibermedios en España. Eunsa: Pamplona, pp. 166-177. ISBN: 9788431331252.

Vázquez-Herrero, Jorge; Direito-Rebollal, Sabela; Silva-Rodríguez, Alba; López-García, Xosé (eds.) (2020). Journalistic metamorphosis. Media transformation in the digital age. Cham: Springer. ISBN: 9783030363147

Vázquez-Herrero, Jorge; Negreira-Rey, María-Cruz; López-García, Xosé (2019). “La innovación multimedia e interactiva en el ciberperiodismo argentino". Revista de comunicación, v. 18, n. 1, pp. 191-214.

https://doi.org/10.26441/RC18.1-2019-A10

Vázquez-Herrero, Jorge; Negreira-Rey, María-Cruz; Pereira-Fariña, Xosé (2017). "Contribuciones del documental interactivo a la renovación de las narrativas periodísticas: realidades y desafíos". Revista latina de comunicación social, n. 72, pp. 397-414.

https://doi.org/10.4185/RLCS-2017-1171

Vieira-de-Araújo, Lucas (2019). "Main innovation initiatives in communication in Brazil and their relationship with the ecosystem". Organicom, v. 16, n. 31, pp. 83-101.

https://doi.org/10.11606/issn.2238-2593.organicom.2019.159694 
Villi, Mikko; Grönlund, Mikko; Linden, Carl-Gustav; Lehtisaari, Katja; Mierzejewska, Bozena; Picard, Robert G.; Röpnack, Axel (2019). "They're a little bit squeezed in the middle": strategic challenges for innovation in US Metropolitan newspaper organisations". Journal of media business studies, v. 17, n. 1, pp. 33-50.

https://doi.org/10.1080/16522354.2019.1630099

Villi, Mikko; Picard, Robert G. (2018). "Transformation and innovation of media business models". In: Deuze, Mark; Prenger, Mirjam (eds.). Making media. Production, practices, and professions. Amsterdam: Amsterdam University Press, pp. 121-131. ISBN: 9789462988118

Virta, Sari; Lowe, Gregory-Ferrell (2016) “Crossing boundaries for innovation: Content development for PSM at Yle”. In: Lowe, Gregory-Ferrel; Yamamoto, Nobuto (eds.). Crossing borders and boundaries in public service media. RIPE@2015. Göteborg: Nordicom, pp. 229-246. ISBN: 9789187957215

Virta, Sari; Malmelin, Nando (2017). “Ambidextrous tensions: Dynamics of creative work in the media innovation process". The journal of media innovations, v. 4, n. 1, pp. 44-59.

https://doi.org/10.5617/jmi.v4i1.2410

Von-Nordheim, Gerret; Boczek, Karin; Koppers, Lars (2018). “Sourcing the sources: An analysis of the use of Twitter and Facebook as a journalistic source over 10 years in The New York Times, The Guardian, and Süddeutsche Zeitung". Digital journalism, v. 6, n. 7, pp. 807-828.

https://doi.org/10.1080/21670811.2018.1490658

Wagemans, Andrea; Witschge, Tamara (2019). "Examining innovation as process: Action research in journalism studies". Convergence: the international journal of research into new media technologies, v. 25, n. 2, pp. 209-224. https://doi.org/10.1177/1354856519834880

West, Joel; Bogers, Marcel (2014). "Leveraging external sources of innovation: a review of research on open innovation". Journal of product innovation management, v. 31, n. 4, pp. 814-831.

https://doi.org/10.1111/jpim.12125

Westlund, Oscar; Krumsvik, Arne H. (2014). "Perceptions of intra-organizational collaboration and media workers' interests in media innovations". The Journal of media innovations, v. 1, n. 2, pp. 52-74.

https://doi.org/10.5617/jmi.v1i2.858

Westlund, Oscar; Krumsvik, Arne H.; Lewis, Seth C. (2021). “Competition, change, and coordination and collaboration: tracing news executives' perceptions about participation in media innovation". Journalism studies, v. 22, n. 1. https://doi.org/10.1080/1461670X.2020.1835526

Westlund, Oscar; Lewis, Seth C. (2014). "The agents of media innovation activities: Actors, actants, and audiences". The journal of media innovations, v. 1, n. 2, pp. 10-35. https://doi.org/10.5617/jmi.v1i2.856

Witschge, Tamara; Deuze, Mark; Willemsen, Sofie (2019). "Creativity in (digital) journalism studies: Broadening our perspective on journalism practice". Digital journalism, v. 7, n. 7, pp. 972-979.

https://doi.org/10.1080/21670811.2019.1609373

Wood-Adams, Jennifer (2008). "Innovation management and U.S. weekly newspaper web sites: An examination of newspaper managers and emerging technology". International journal on media management, v. 10, n. 2, pp. 64-73. https://doi.org/10.1080/14241270802000454

Wu, Yanfang (2019). "How age affects journalists' adoption of social media as an innovation: A multi-group SEM analysis". Journalism practice, v. 13, n. 5, pp. 537-557.

https://doi.org/10.1080/17512786.2018.1511821

Yeo, Tien-Ee-Dominic (2016). “Communicating legitimacy: How journalists negotiate the emergence of user-generated content in Hong Kong". Journalism \& mass communication quarterly, v. 93, n. 3, pp. 609-626. https://doi.org/10.1177/1077699016628823

Zabel, Christian; Telkmann, Verena (2020). "The adoption of emerging technology-driven media innovations. A comparative study of the introduction of virtual and augmented reality in the media and manufacturing industries". Journal of media business studies, online first.

https://doi.org/10.1080/16522354.2020.1839172

Zamith, Rodrigo; Lewis, Seth C. (2014). "From public spaces to public sphere: Rethinking systems for reader comments on online news sites". Digital journalism, v. 2, n. 4, pp. 558-574.

https://doi.org/10.1080/21670811.2014.882066 
Zaragoza-Fuster, María-Teresa; García-Avilés, José-Alberto (2018). “Desarrollo de la innovación periodística en la televisión pública: El caso del RTVE Lab". Hipertext.net: revista académica sobre documentación digital y comunicación interactiva, v. 17, n. 4.

https://doi.org/10.31009/hipertext.net.2018.i17.02

Zaragoza-Fuster, María-Teresa; García-Avilés, José-Alberto (2020). "The role of innovation labs in advancing the relevance of Public Service Media: the cases of BBC News Labs and RTVE Lab". Communication \& society, v. 33, n. 1, pp. 45-61.

https://doi.org/10.15581/003.33.1.45-61

Zayani, Mohamed (2020). "Digital journalism, social media platforms, and audience engagement: The case of AJ+". Digital journalism, online first.

https://doi.org/10.1080/21670811.2020.1816140

Zhang, Shixin-Ivy (2019). "The business model of journalism start-ups in China". Digital journalism, v. 7, n. 5, pp. 614634.

https://doi.org/10.1080/21670811.2018.1496025

Zhang, Shuling; Feng, Jieyun (2019). "A step forward? Exploring the diffusion of data journalism as journalistic innovations in China". Journalism studies, v. 20, n. 9, pp. 1281-1300.

https://doi.org/10.1080/1461670X.2018.1513814

Zhou, Yuqiong (2008). "Voluntary adopters versus forced adopters: integrating the diffusion of innovation theory and the technology acceptance model to study intra-organizational adoption". New media \& society, v. 10, n. 3, pp. 475-496. https://doi.org/10.1177/1461444807085382

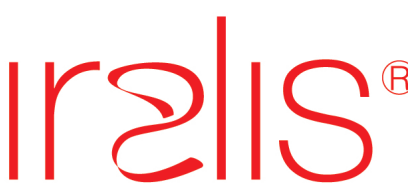

International Registry for Authors: Links to Identify Scientists

es:

- una guía para los autores hispanos para que firmen sus trabajos en el formato internacional usual

- una base de datos que registra las variantes de firma usadas por cada autor en diferentes épocas

- un buscador que usa automáticamente todas las variantes registradas

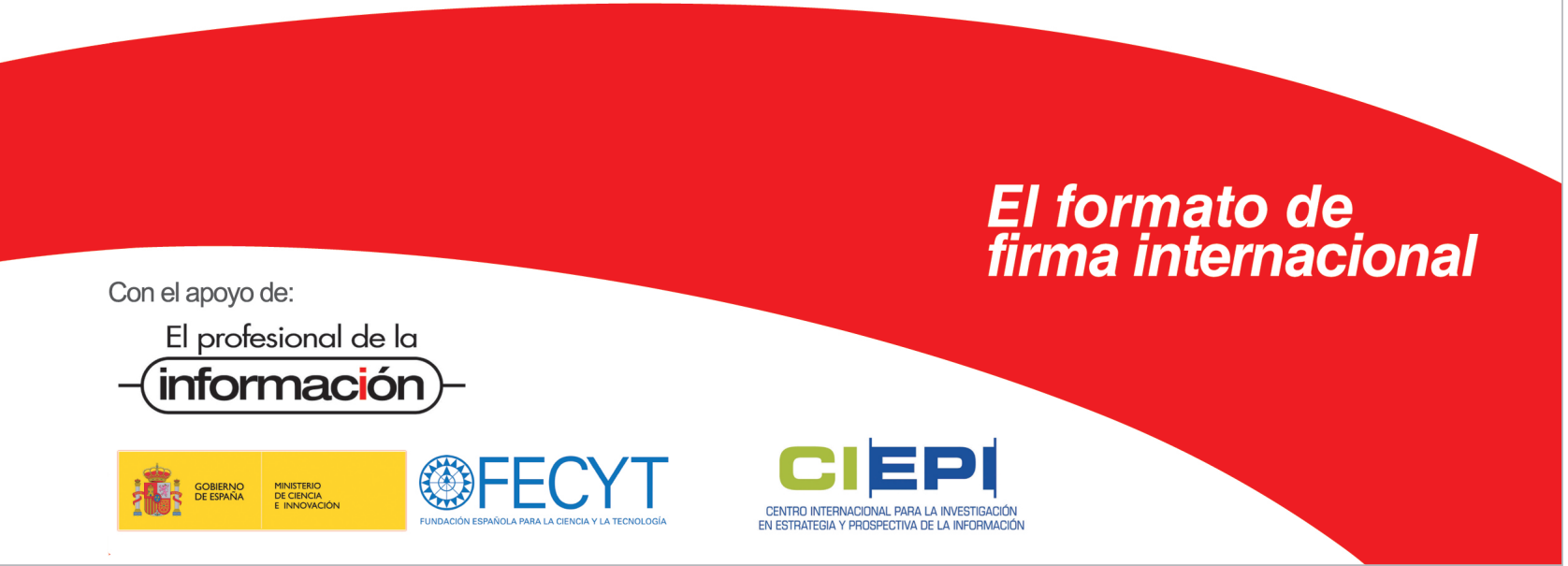

